\title{
Geochemistry of marine and lacustrine bands in the Upper Carboniferous of the Netherlands
}

\author{
H. Kombrink ${ }^{1,2}$, B.J.H. van $0 s^{3}$, C.J. van der $Z_{w a n}^{4}$ \& Th.E. Wong ${ }^{2}$ \\ 1 Corresponding author. TNO Built Environment and Geosciences - Geological Survey of the Netherlands, Princetonlaan 6, 3584 CB Utrecht, \\ the Netherlands. Email: hkombrink@gmail.com \\ 2 Utrecht University, Faculty of Geosciences, Stratigraphy and Paleontology, Budapestlaan 4, 3584 CD Utrecht, the Netherlands. \\ 3 Rijksdienst voor Archeologie, Cultuurlandschap en Monumenten (RACM), P.0. Box 1600, 3800 BP Amersfoort, the Netherlands. \\ 4 Shell Technology India, RMZ Centennial Campus B No. 8 Kundanahali Main road, Bangalore 560048, India.
}

Manuscript received: November 2007; accepted: 0ctober 2008

\begin{abstract}
Geochemical studies on Upper Carboniferous marine bands showed that marked enrichment in redox-sensitive trace elements (uranium (U), vanadium (V), molybdenum (Mo)) mostly occur if they contain Goniatites. Goniatites indicate deposition in relatively distal and deep marine environments. In contrast, Westphalian marine bands found in the Netherlands predominantly show a Lingula facies, indicating deposition in a nearshore environment. These Lingula marine bands are mostly lacking significant trace element enrichments. The aim of this paper is to explain the mechanisms causing the differences in geochemical characteristics between distal (Goniatites facies) and proximal (Lingula facies) marine bands. Geochemical analyses (total organic carbon (TOC), sulfur (S), major and trace elements) were carried out on a selection of these marine bands. Furthermore, a comparison was made with some lacustrine bands which broadly show the same sedimentary development as the Lingula marine bands. The results show that the Lingula marine bands, in contrast to the Goniatites and lacustrine bands, are characterised by low organic carbon contents $(1-2 \mathrm{wt} . \%)$. A relatively high input of siliciclastics probably prevented the accumulation of organic-rich layers (dilution effect). In turn, low organic carbon contents most likely prevented the effective scavenging of trace elements. Although the lacustrine bands are characterised by high TOC contents, here the limited availability of trace elements in fresh water forms the best explanation for low trace metal enrichments. Since marine bands form stratigraphically important horizons in the Upper Carboniferous, many attempts have been made to recognise marine bands using well logs (gamma-ray). The results from this study show that using gamma-ray devices (detecting U-enrichments), only marine bands in a Goniatites facies are clearly recognised while Lingula marine bands are not detected.
\end{abstract}

Keywords: Carboniferous, geochemistry, lacustrine bands, marine bands, the Netherlands

\section{Introduction}

The Upper Carboniferous of the Netherlands and surrounding areas consists of a fluvio-deltaic succession with a thickness of up to $5 \mathrm{~km}$. In this succession, marine bands form important stratigraphic horizons since these are thought to be correlatable basinwide (Ramsbottom et al., 1979; Leeder, 1988; Leeder et al., 1990; Dusar et al., 2000; Fig. 1). Marine bands are relatively thin layers $(<1-30 \mathrm{~m})$ of fine-grained sediment (clay to siltfraction; $1-50 \mu \mathrm{m}$ ) characterised by the presence of marine (micro)fossils. The origin of marine bands is commonly attributed to (glacio-eustatic) sea-level rises (Holdsworth \& Collinson, 1988; Martinsen et al., 1995). Based on fossil content, Calver (1969), Rabitz (1966) and Ramsbottom (1969) distinguished several faunal phases in marine bands, reflecting the relative position to the shoreline. The fossils indicating the deepest water and most distal conditions are Goniatites (ammonoids), whereas a Lingula (brachiopod) facies indicates deposition in nearshore or even brackish environments.

Attempts to identify the stratigraphically important marine bands in the Carboniferous succession using well logs or geochemical analyses have long been made. Hoogteijling (1948) 
found the strongest enrichments in $U$ (one of the 3 elements picked up by gamma-ray devices) in the finest sediments but he doubted the possibilities to identify marine bands using gammaray logs. However, De Magnée (1952) thought it is possible to distinguish marine bands using gamma-ray logs. More recently, several authors showed - using spectral gamma-ray (Archard \& Trice, 1990; Hollywood \& Whorlow, 1993; Davies \& McLean, 1996) or geochemical analyses (Bloxham \& Thomas, 1969; Spears, 1964; Fisher \& Wignall, 2001) - that the Goniatites facies in marine bands often display enhanced U-concentrations. They concluded that an extremely slow sedimentation rate under anoxic and organic rich conditions favours enrichment in U. Indeed, the Goniatites facies in marine bands often shows enhanced organic matter contents (Calver, 1969; Ramsbottom, 1969). The term black shale has therefore often been used as a descriptive term for these U-enriched marine bands.
The marine bands found in the Netherlands mostly display a Lingula facies (Table 1) and (spectral) gamma-ray logs show weak or only faint peaks (Fig. 2). For instance, it can be seen that in the well Kemperkoul-1 (KPK-1) the marine band named Domina does not show a clear peak. Moreover, when a peak can be seen (for instance in the Aegir marine band in $\mathrm{KPK}-1$ ), it turns out to be located in the coal underlying the marine band.

Most geochemical work has been performed on Goniatites marine bands. The availability of some continuously cored wells in the Netherlands, in which Lingula bands already are proven by fossil evidence, provides an excellent dataset to study the geochemical characteristics of these type of marine bands. The aims of this paper are to (1) explain the geochemical development of (proximal marine) Lingula marine bands and (2) put them into perspective using data from

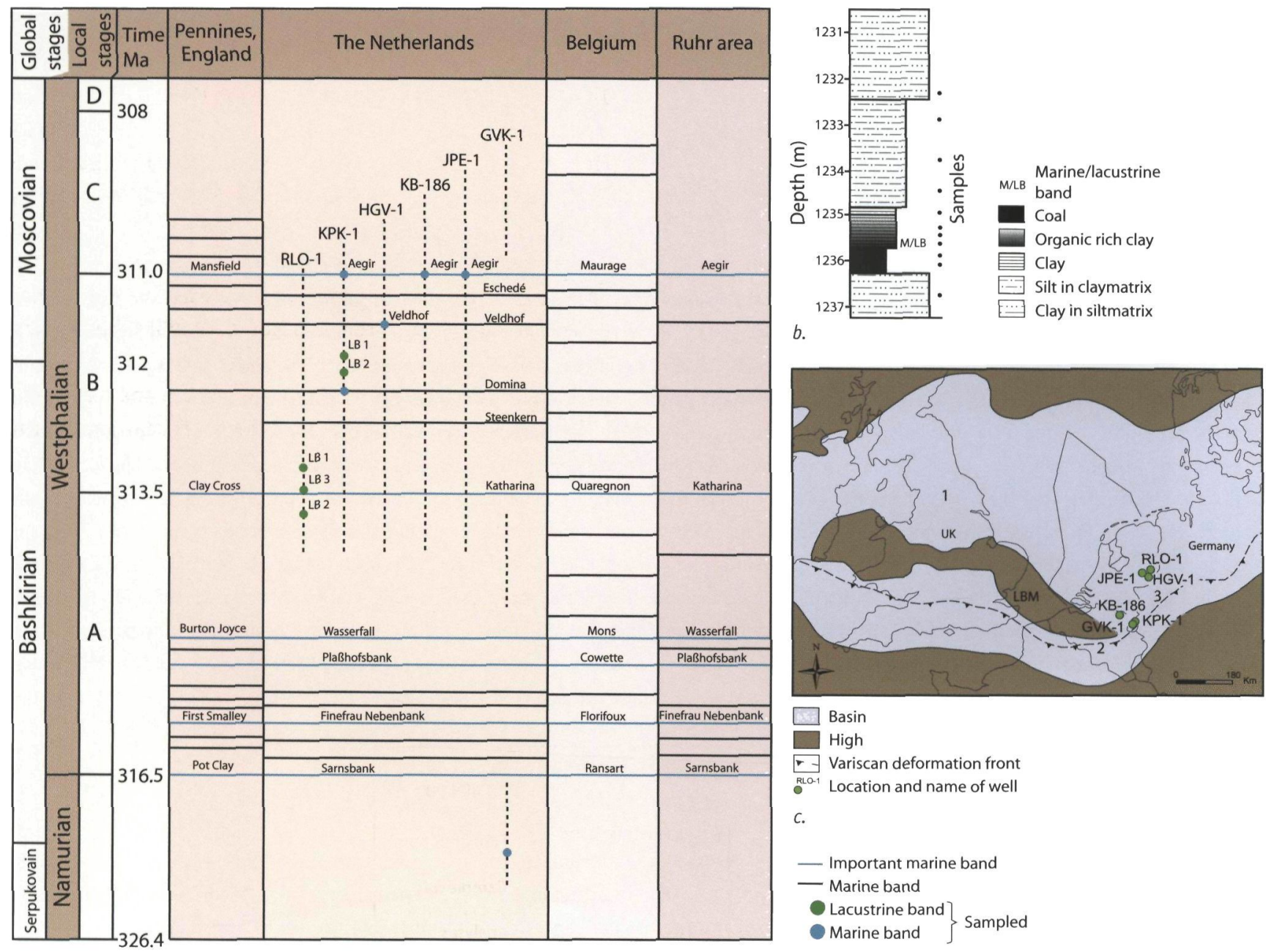

a.

Fig. 1. a. Stratigraphic distribution of sampled sections, next to distribution of Westphalian marine bands recognised in the UK (Calver, 1967), Belgium (Paproth et al. 1983), the Netherlands (Thiadens (1963) and several biostratigraphy reports) and the Ruhr Basin (Drozdzewski, 2005). Note that the number of marine bands mentioned in the text does not always exactly correspond with the number of marine bands showed in this diagram because some have been grouped for clarity. The large number of Namurian marine bands is not shown in this figure. RLO-1: Ruurlo-1; KPK-1: Kemperkoul-1; HGV1: Hengevelde-1; KB-186: Kolen boring-186; JPE-1: Joppe-1; GVK-1: Geverik-1; LB: Lacustrine band; b. Generalised sedimentary log of a marine/lacustrine band; and c. Outlines of Northwest European Carboniferous Basin. 1: Pennines, UK, 2: Belgium, 3: Ruhr area, LBM: London Brabant Massif. Figure 1C modified after Ziegler (1990). Timescale after Gradstein et al. (2004). 
Table 1. Fossil content of sampled sections. Fossils indicating marine conditions are: Goniatites, Conodonts, Orbiculoidea and marine ostracods. Brackish conditions are reflected by Lingula and Foraminifers. Fresh water conditions are interpreted when Carbonita and Geisina are found. When no fossils were found, a fresh water depositional environment is assumed because of the findings of fresh water fossils directly above and below the sections.

\begin{tabular}{lll}
\hline Section & & Fossils \\
\hline Marine bands & GVK-Goniatites MB & Goniatites \\
GPK-Aegir & $\begin{array}{l}\text { Foniatites, Conodonts, } \\
\text { ostracods, Lingula }\end{array}$ \\
& & $\begin{array}{l}\text { Foraminifers, Lingula, } \\
\text { Orbiculoidea }\end{array}$ \\
& KPK-Domina & Marine ostracods, \\
& JPE-Aegir & Foraminifers \\
& & Lingula, Trilobite, Conularia \\
& KB-Aegir & Foraminifers, Lingula \\
\hline Lacustrine bands & RLV-Veldhof & - \\
& RLO-LB 1 & Geisina arcuata \\
& RLO-LB 2 & - \\
& RLO-LB 3 & Carbonita \\
& KPK-LB 1 & - \\
\hline
\end{tabular}

(distal marine) Goniatites marine bands and lacustrine bands (reflecting entirely fresh water conditions). In this way, a transect from lacustrine up to (deep) marine conditions will be investigated. Published geochemical data from the UK has been used to further illustrate the results.

\section{Geological setting}

During Namurian times, sedimentation in the Northwest European Carboniferous Basin (NWECB, Fig. 2) mainly took place under deltaic conditions. In general, the lower part of the Namurian sequence is characterised by pro-delta basinal shale, giving way to typical coarsening and shallowing-upward cycles of pro-delta shale via fluvial silt/sandstone to a coal. The marine bands are intercalated between the basinal shale or overlie the coal, reflecting the peak of transgression where most distal conditions are reached. Glacio-eustatic sea-level fluctuations probably form the driving mechanism of the observed cyclicity and deposition of marine bands in the NWECB. During the Westphalian these cycles are gradually replaced by continuous fluvial sedimentation characterised by the alternation of fluvial channel sands, floodplain mudstones and paralic coals. The Westphalian marine bands are mostly found on top a coal.

Marine bands were extensively studied in the UK (Calver, 1969; Ramsbottom, 1969), Belgium (Paproth et al., 1983; Dusar et al., 2000) and the Ruhr area in Germany (Rabitz, 1966; Fig. 1). In the Namurian succession, numerous marine bands $(>30)$ were found (not shown in figure 1). The UK Westphalian succession contains 19 marine bands (Calver, 1969), whereas in Germany, 15 marine bands occur (Rabitz, 1966). In the Netherlands, 14 marine bands are found in the Westphalian (Thiadens, 1963; Van Amerom \& Meessen, 1985; Van Amerom et al., 1985). Most of the Namurian marine bands are developed in Goniatites facies, representing deep marine and distal conditions. However, most of the Westphalian marine bands have
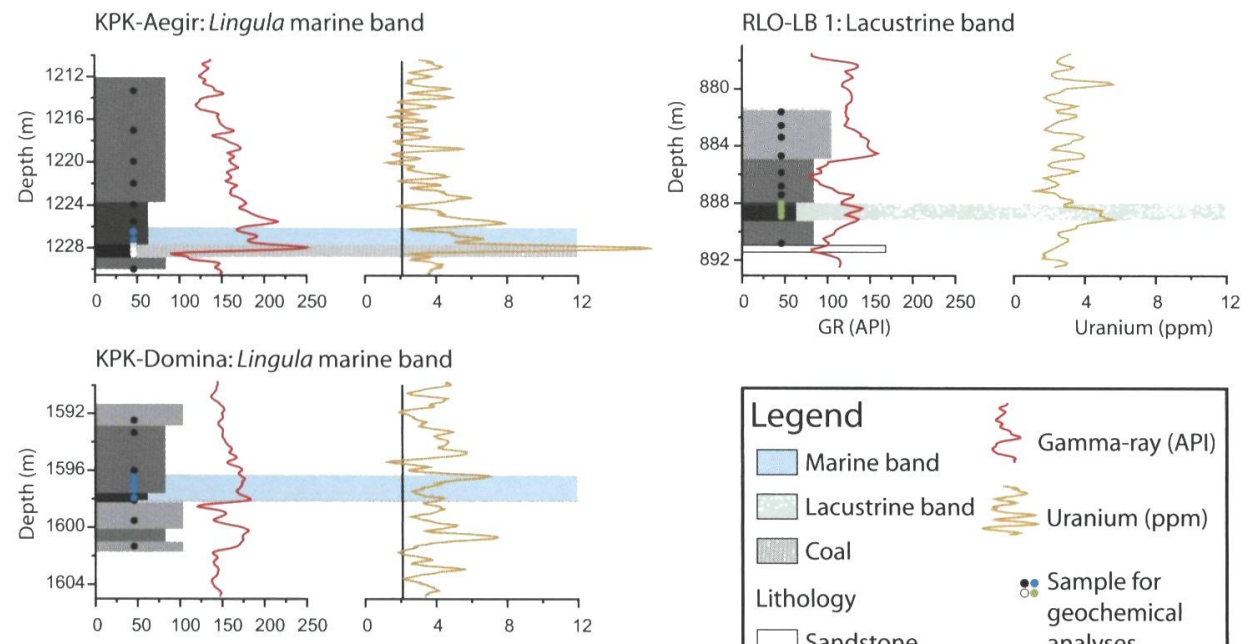

\begin{tabular}{|c|c|}
\hline $\begin{array}{l}\text { Legend } \\
\square \text { Marine band } \\
\square \text { Lacustrine band } \\
\square \text { Coal } \\
\text { Lithology } \\
\square \text { Sandstone } \\
\square \text { Siltstone } \\
\square \text { Silty claystone } \\
\square \text { Clayey siltstone } \\
\text { Claystone } \\
\text { Claystone - high C } \\
\text { Coal }\end{array}$ & $\begin{array}{l}\text { Gamma-ray (API) } \\
\text { Sample for } \\
\text { geochemical } \\
\text { analyses } \\
\text { - Sample from } \\
\text { marine band } \\
\text { - Sample from } \\
\text { lacustrine band }\end{array}$ \\
\hline
\end{tabular}

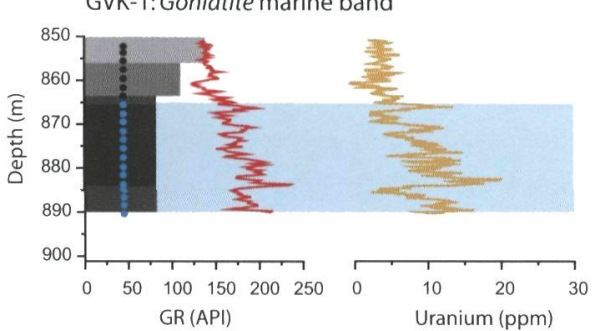

Fig. 2 Some examples of well log response (gamma-ray and spectral gamma-ray (uranium plotted here) and sonic) for marine and lacustrine bands. Sample locations are given. Note the scale change for the uranium-log in GVK-1. 
a Lingula facies and only a limited number displays (Fig. 1) a Goniatites facies (Calver, 1969; Drozdzewski, 2005). Extensive research on the fossil content of marine bands in the UK and Germany showed that one marine band can be developed in different faunal phases laterally and on one location. Lingula facies mainly occurs along basin margins and intervening highs such as the London Brabant Massif (Fig. 1), whereas the Goniatites marine bands are found in the basin centre (Calver, 1969; Ramsbottom, 1969). Moreover, the most complete record of marine bands is found in the basin centre as certain bands are lacking in the marginal areas (Calver, 1969). For example, marine bands change from Lingula to Goniatites facies across the Craven fault in the Pennines (Calver, 1969).

\section{Data}

In the 1980s, the Netherlands Geological Survey drilled five wells with complete core coverage of the Carboniferous (Fig. 1): Ruurlo-1 (RLO-1), Joppe-1 (JPE-1), Hengevelde-1 (HGV-1), Kemperkoul-1 (KPK-1) and Geverik-1 (GVK-1). 148 samples from 11 intervals (Fig. 1 and Table 2) were taken from these cores stored in the core-lab of TNO - Netherlands Geological Survey. The Lingula marine band KB-Aegir was sampled in the core-lab of the Geological Survey of Belgium in Brussels.

Table 2. Depth of sampled intervals, number of samples taken and thickness of investigated sections. The last column shows the maturity of the sections.

\begin{tabular}{|c|c|c|c|c|c|}
\hline Section & $\begin{array}{l}\text { Depth } \\
\text { (m) }\end{array}$ & $\begin{array}{l}\text { Number } \\
\text { of } \\
\text { samples }\end{array}$ & $\begin{array}{l}\text { Interval } \\
\text { thickness } \\
\text { (m) }\end{array}$ & $\begin{array}{l}\text { Thickness } \\
\text { marine/ } \\
\text { lacustrine } \\
\text { band (m) }\end{array}$ & $\begin{array}{l}\text { Vitrinite } \\
\text { reflectance } \\
(\% \mathrm{RM})\end{array}$ \\
\hline GVK-Gon. MB & $850-890$ & 21 & 40 & 25 & $>3$ \\
\hline KPK-Aegir & 1226 & 17 & 30 & 0.8 & 0.82 \\
\hline KPK-LB 1 & 1495 & 11 & 4 & 0.9 & 1.08 \\
\hline KPK-LB 2 & 1571 & 10 & 4 & 0.2 & 1.16 \\
\hline KPK-Domina & 1597 & 11 & 10 & 1.5 & 1.16 \\
\hline JPE-Aegir & 1300 & 18 & 15 & 7.8 & 0.82 \\
\hline KB-Aegir & 1130 & 9 & 5 & 1.4 & 1.07 \\
\hline HGV-Veldhof & 1242 & 12 & 3 & 0.8 & 0.75 \\
\hline RLO-LB 1 & 888 & 13 & 9 & 0.9 & 1.01 \\
\hline RLO-LB 2 & 1184 & 11 & 4 & 0.5 & 1.15 \\
\hline RLO-LB 3 & 1235 & 15 & 6 & 0.8 & 1.29 \\
\hline
\end{tabular}

Five lacustrine bands, five Lingula marine bands and one Goniatites marine band were sampled. The Lingula marine bands were selected on the basis of the fossil content derived from the cores. Sampling of the Goniatites marine band was performed on the basis of spectral gamma-ray and fossil content. The spectral gamma-ray log shows enhanced uranium contents (Fig. 2) whereas the findings of numerous Goniatites point to a marine depositional environment (Table 1 ). The thickness of this marine band is relatively high $(25 \mathrm{~m})$. The lacustrine bands were selected on the basis of sedimentological criteria (parallel laminated, fine-grained and TOC-rich sediments). No fossils were found in three lacustrine sections (Table 1). However, a fresh water environment is assumed, based on the presence of fresh water fossils immediately below and above the sections (Van Amerom \& Glerum, 1984; Meessen, 1985).

The investigated marine bands form a small subset of the total amount that has been recognised (Fig. 1). The stratigraphically lowest Westphalian marine band studied in this paper is Domina, which has a Middle Westphalian B age. In the Ruhr basin, Domina has only been found in the northwestern part, indicating a continuation of paralic sedimentation in the southeast (Drozdzewski, 2005). The Veldhof marine band was discovered in the 1980's and has been tentatively correlated with German marine bands (Van Amerom \& Meessen, 1985). The most important marine band that was sampled is the Aegir. It has a rich fauna in the Ruhr Basin (Rabitz, 1966), where it can attain a thickness of $30 \mathrm{~m}$. This is the last fully marine flooding in this part of the NWECB (in the UK the Top marine band is found in Middle Westphalian $C$ sediments). In KPK- 1 and JPE-1, the Aegir is characterised by some Goniatiteremains but these occur together with other fossils (Table 1 ).

From a sedimentological point of view, the Lingula bands are comparable to the lacustrine bands (Figs 2 and 3). Both are characterised by the following sedimentary succession: at the base a grey and mostly mottled clayey siltstone occurs, deposited in a floodplain where bioturbation caused mixing of the sediments. This floodplain was drowned and peat formation started, resulting in a coal of variable thickness (usually $<1 \mathrm{~m}$ ). In case of the Lingula bands, seawater flooded the swamps and shallow marine conditions were established. A lacustrine setting developed because subsidence probably exceeded peat-growth. In both cases parallel laminated clay, (slightly) enriched in organic matter was subsequently deposited. Organic carbon contents decrease upwards and parallel lamination gives way to ripple lamination while bioturbation increases. In turn, the shallow marine and lacustrine sediments are overlain by fluvial mouthbar or channel sandstones and fine grained sediments deposited in floodplains. The Namurian Goniatites marine band of the Geverik well entirely consists of a claystone, deposited under relatively deep marine conditions. The sediments are well laminated and dark coloured because of the high organic matter content. Going upwards, the first pro-delta coarsening upward sequence marks the onset of the Namurian basin fill.

\section{Methods}

All samples were ground to small particle size using a Tungstencarbide mill in an automated grinding machine (Herzog HSMHTP). X-ray fluorescence spectometry (XRF) was carried out on glass beads to obtain major element concentrations (see Table 3 for precision). The glass beads were analysed using an ARL9400 spectrometer with an $\mathrm{Rh}$ tube with full matrix correction for 


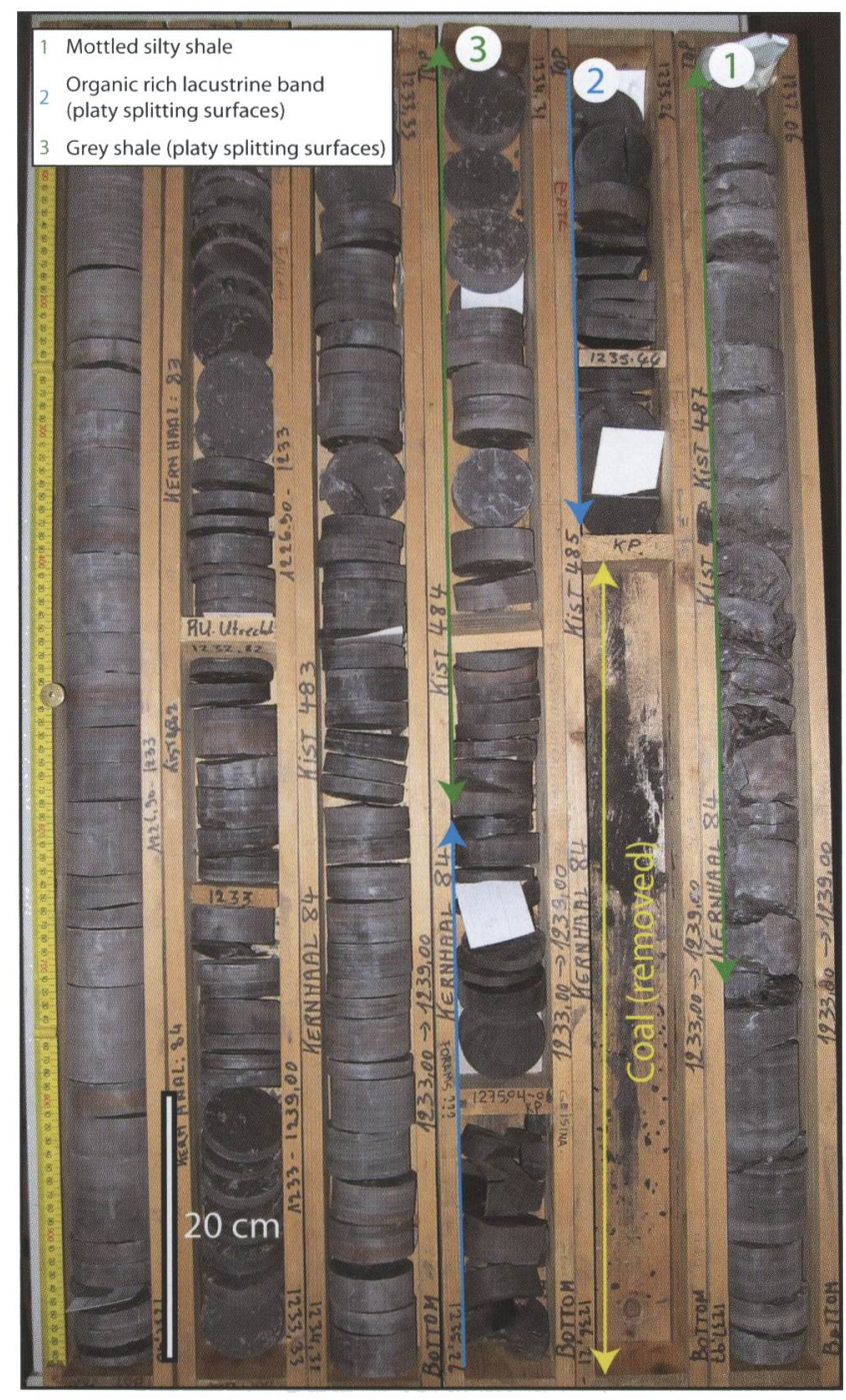

Fig. 3. Core-photograph of a lacustrine band (RLO-LB 2). The mottled sediment (1) below the coal is well developed, as well as the organic-rich section (2) on top of the coal (lacustrine band). The white labels indicate the sample locations. major elements. However, before XRF analysis could be carried out, TGA (thermo-gravometric analysis) was performed on 3 $4 \mathrm{~g}$ of grounded samples, using a LECO ${ }^{\circledR}$ TGA 601. The TGA results were used for the determination of the moisture $\left(105^{\circ} \mathrm{C}\right)$, organic matter $\left(450-550^{\circ} \mathrm{C}\right)$ and carbonate content $\left(800-1100^{\circ} \mathrm{C}\right)$.

Total carbon content (TC) and total sulphur content (TS) were obtained using a LEC ${ }^{\circledR}$ SC 144DR C/S analyzer. Determination of the total organic carbon content (TOC) was carried out by subtracting the carbon content attributed to $\mathrm{CaO}$ (obtained by $\mathrm{XRF}$ ) from the TC content. This corresponds well with the determination of TOC using carbonate from the TGA-results (not shown). Due to maturation, some loss of organic matter took place. However, except for GVK-1 the original TOC values have not been restored. There are two reasons for this: 1) the maturities of these sections are well comparable and not very high and 2) probably most of the organic matter is of terrestrial origin, implying only moderate loss of organic matter. Using the method published by Raiswell \& Berner (1987), the original TOC for GVK-1 will fall within a range of $8-10 \mathrm{wt} \%$.

It is assumed, based on Leeder et al. (1990), that the total sulphur concentrations obtained from the siliciclastic sediments are present in the form of pyrite. When plotted against Fe (Fig. 4), most of the samples with clear enrichment in sulphur are situated near the pyrite line, which indeed suggests the dominant residence of sulphur in pyrite. Based on studies by Diessel (1992) and Spears et al. (1999) it is also assumed that enrichments in sulphur $(>1.5 \mathrm{wt} \%)$ in the coals analysed in this study are caused by pyrite.

HF-based destruction of $125 \mathrm{mg}$ of pulverised sample was carried out to measure trace elements by ICP-MS. The solutions were analyzed by an Agilent 7500 ICP-MS with a low uptake nebulizer. The analytical quality of the XRF, C/S and ICP-MS analyses was determined by calculation of the precision of duplicate sample pairs. Accuracy was calculated with the mean

Table 3. Precision and accuracy of C/S (LECO), XRF (only precision) and ICP-MS analyses for elements used in this paper. Concentrations for C/S and XRF: $w t \%$, for ICP-MS: $\mathrm{mg} / \mathrm{kg}$ (nd $=$ not determined).

\begin{tabular}{|c|c|c|c|c|c|c|c|}
\hline \multirow[b]{2}{*}{ Element } & \multirow[b]{2}{*}{ Method } & \multicolumn{3}{|c|}{ Precision } & \multicolumn{3}{|l|}{ Accuracy } \\
\hline & & Mean & Precision $(\sigma)$ & $2 \sigma(\%)$ & Mean & Standard & Accuracy (\%) \\
\hline TS (wt \%) & LECO & 1.52 & 0.02 & 2.64 & 0.51 & 0.50 & 2.40 \\
\hline $\mathrm{TC}(\mathrm{wt} \%)$ & LECO & 2.00 & 0.06 & 5.99 & 3.91 & 3.60 & 8.60 \\
\hline $\mathrm{Al}(\mathrm{wt} \%)$ & XRF & 18.57 & 0.11 & 1.18 & nd & nd & nd \\
\hline $\mathrm{Fe}(\mathrm{wt} \%)$ & XRF & 6.31 & 0.03 & 0.95 & nd & nd & nd \\
\hline $\mathrm{K}(w t \%)$ & XRF & 3.69 & 0.04 & 2.17 & nd & nd & nd \\
\hline $\mathrm{Ca}(\mathrm{wt} \%)$ & XRF & 0.28 & 0.01 & 7.05 & nd & nd & nd \\
\hline Mo $(\mathrm{mg} / \mathrm{kg})$ & ICP-MS & 2.91 & 0.11 & 7.57 & 1.20 & 1.14 & .5 .22 \\
\hline $\mathrm{U}(\mathrm{mg} / \mathrm{kg})$ & ICP-MS & 3.98 & 0.16 & 8.04 & 2.28 & 2.31 & -1.18 \\
\hline $\mathrm{V}(\mathrm{mg} / \mathrm{kg})$ & ICP-MS & 126.16 & 8.51 & 13.49 & 87.41 & 92.00 & -4.99 \\
\hline $\mathrm{Zn}(\mathrm{mg} / \mathrm{kg})$ & ICP-MS & 105.67 & 6.61 & 12.52 & 622.31 & 528.00 & 17.86 \\
\hline $\mathrm{Pb}(\mathrm{mg} / \mathrm{kg})$ & ICP-MS & 256.03 & 3.04 & 2.38 & 164.39 & 167.00 & -1.56 \\
\hline $\mathrm{Ni}(\mathrm{mg} / \mathrm{kg})$ & ICP-MS & 63.82 & 5.01 & 15.71 & 42.85 & 43.60 & -1.72 \\
\hline $\mathrm{Cu}(\mathrm{mg} / \mathrm{kg})$ & ICP-MS & 46.58 & 2.72 & 11.68 & 90.16 & 95.00 & -5.10 \\
\hline Th $(\mathrm{mg} / \mathrm{kg})$ & ICP-MS & 10.29 & 0.76 & 14.77 & 9.28 & 9.74 & -4.72 \\
\hline
\end{tabular}




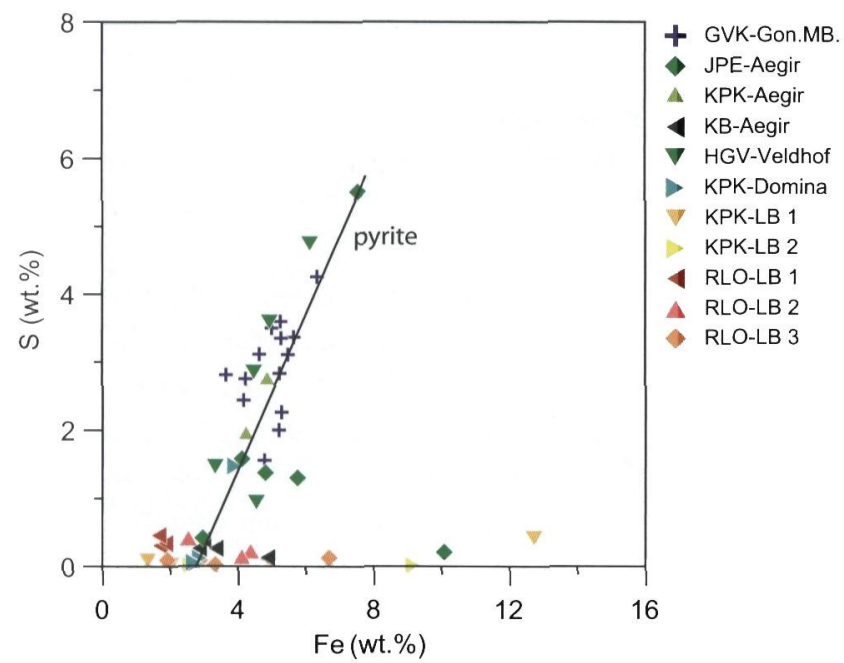

Fig. 4. Cross-plot displaying the $\mathrm{Fe} / \mathrm{S}$ ratio for the marine and lacustrine bands. The samples enriched in pyrite plot relatively well on the pyrite line. PAAS: Post Archean Average Shale.

values of the standard measurements and the reported mean element concentrations of these standards (Table 3 ).

Trace elements enrichment factors (EF) were calculated for a number of elements. The mean EF for a particular marine/ lacustrine band or overlying sediment layer is based on the following formula:

$$
E F=\frac{\sum_{i=1}^{N}(E l / A l)_{\text {sample }} /(E l / A l)_{\text {av. shale }}}{N}
$$

where $E l$ and $A l$ are the trace element and aluminium concentrations (ppm) respectively for the average shale (av.shale) and sample (Taylor \& McLennan, 1985) whilst $N$ refers to the number of samples taken from the marine band or overlying sediments. Normalisation on $\mathrm{Al}$ has been carried out to remove the effect of the changing clay-percentages per sample. The EF for coal has been calculated in a different way because Al concentrations are very low in coal (Dellwig, 1999). Moreover, some trace elements may have an association with organic matter (Goodarzi \& Swaine, 1993) which causes normalisation on $\mathrm{Al}$ alone to overestimate the enrichment. Therefore, world mean trace elemental concentrations in coal were used (Swaine, 1990; Gayer et al., 1999) to calculate the EF. The following formula was used:

$$
E F=\frac{\sum_{i=1}^{N}\left(E l_{\text {sample }} / E l_{\text {mean }}\right)}{N}
$$

The following parameters were used to characterise the geochemistry of the marine and lacustrine bands:

1. TOC. Marine bands are often associated with enhanced TOC contents (Bloxham \& Thomas, 1969; Spears \& Sezgin, 1985; Wignall, 1994; Fisher \& Wignall, 2001). The analysis of the sampled sections therefore starts with a description of TOC.
2. Pyrite. Pyrite is often used as an indicator of marine sulphate-reducing conditions (Berner \& Raiswell, 1984). However, clear enrichment of pyrite only occurs under high TOC conditions (when degradable organic matter is present) because under low TOC conditions reduction of sulphate is limited (Lyons et al., 2003).

3. Trace elements. It is widely recognised that marine bands often display enrichment in U (Davies \& McLean, 1996; Leeder et al., 1990; Fisher \& Wignall, 2001) next to other trace elements like Molybdenum (Mo), Vanadium (V), Nickel $(\mathrm{Ni})$, Zinc $(\mathrm{Zn})$, Lead $(\mathrm{Pb})$ and Copper $(\mathrm{Cu})$ (Coveney et al., 1991; Algeo \& Maynard, 2004; Algeo et al., 2004; Schultz, 2004). Enrichment of uranium and other trace elements in marine sediments will only occur if anoxic conditions prevail in the sediments and if there is a source. As the main source for trace elements like U, Mo and V is seawater (Taylor \& McLennan, 1985), these elements will be investigated in particular.

\section{Results}

\section{Organic matter}

The TOC content of the Goniatites marine band varies from 1 to $4.9 \mathrm{wt} \%$, which is an underestimation regarding the very high maturity (see above). In the grey shale on top of the marine band, a mean TOC content of $1 \mathrm{wt} \%$ is common. In general, the Lingula marine bands are characterised by lower TOC contents compared to the Goniatites marine band. A maximum of $4.6 \mathrm{wt} \%$ occurs in HGV-Veldhof whereas in KPKAegir and JPE-Aegir maxima around $2 \mathrm{wt} \%$ were obtained. In KPK-Domina and KB-186, the TOC content is only slightly higher than $1 \mathrm{wt} \%$. The maxima mostly occur in the interval just above the coal and rapidly decrease upward (Fig. 5). The TOC contents in the 'normal' shale on top of the Lingula marine bands vary around $1 \mathrm{wt} \%$, comparable to the values obtained in GVK-1.

In the lacustrine bands, higher TOC contents occur than in both types of marine bands (Fig. 5 \& Appendix 1). A maximum of $40 \mathrm{wt} \%$ was obtained in RLO-LB 1 whereas in KPK-LB 1, RLO-LB 2 and RLO-LB 3 maxima of 17, 7 and $6.6 \mathrm{wt} \%$ occur respectively. Only in KPK-LB 2, TOC contents are comparable to those in the Lingula marine bands; the maximum percentage amounts to $2.4 \mathrm{wt} \%$. The TOC maxima of the lacustrine sections also occur in the interval just on top of the coal and decrease upwards (Fig. 5). The TOC contents of the normal shale overlying the lacustrine bands are comparable to those found in the sections on top of the Lingula marine bands (appr. $1 \mathrm{wt} \%$ ). 

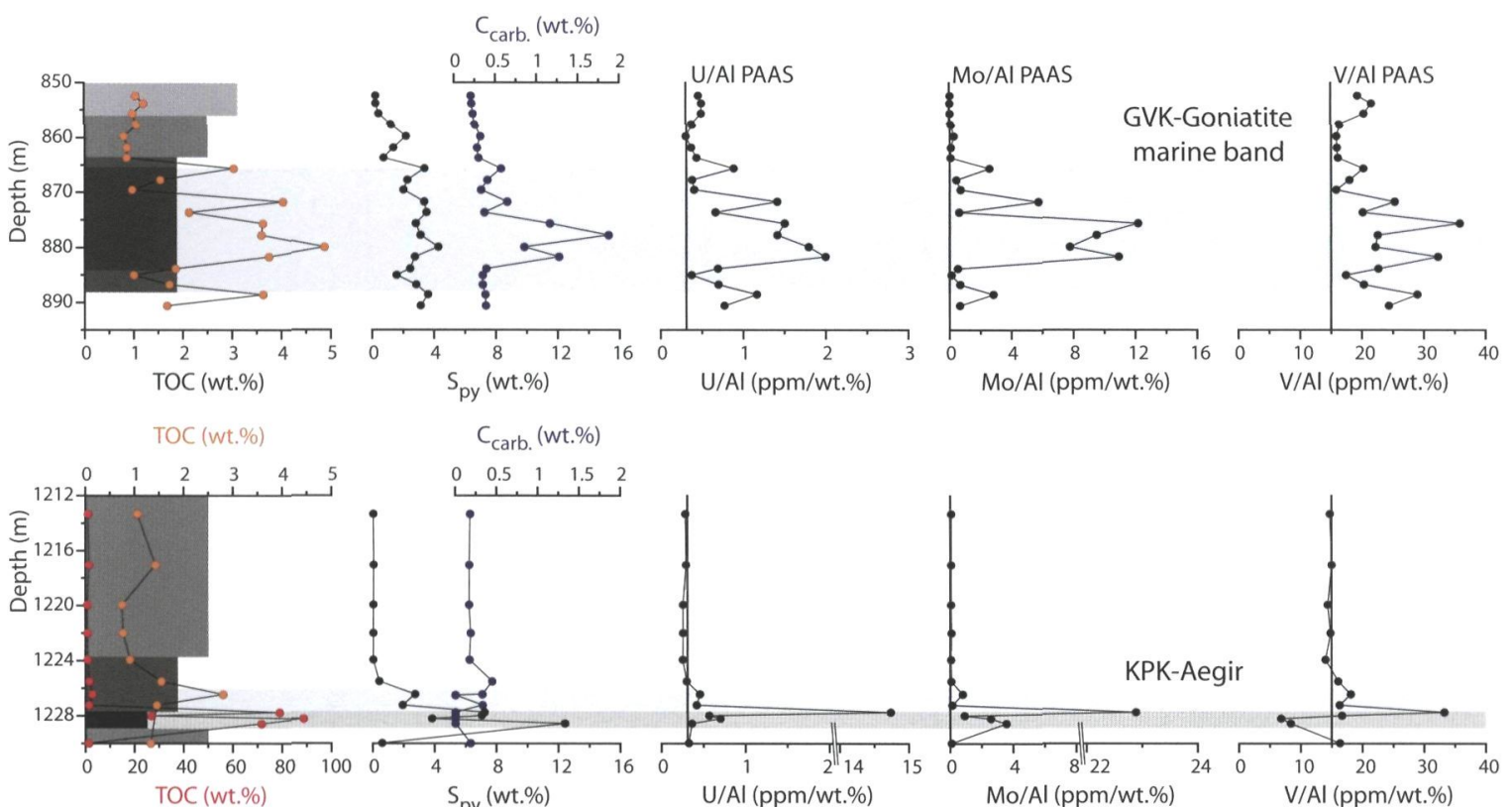

$\mathrm{C}_{\text {carb. }}($ wt.\%)
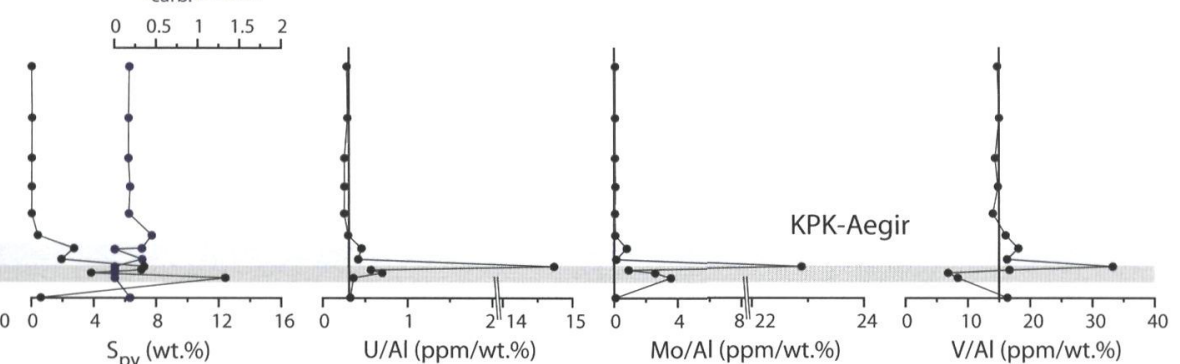

TOC (wt.\%)

$\mathrm{C}_{\text {carb. }}$ (wt.\%)
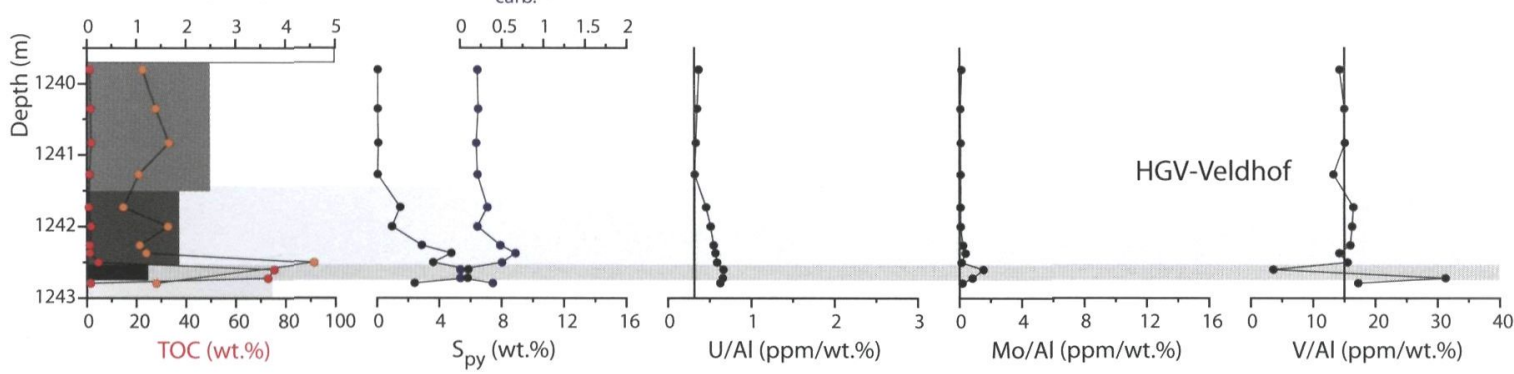

$\mathrm{C}_{\text {carb. }}$ (wt.\%)

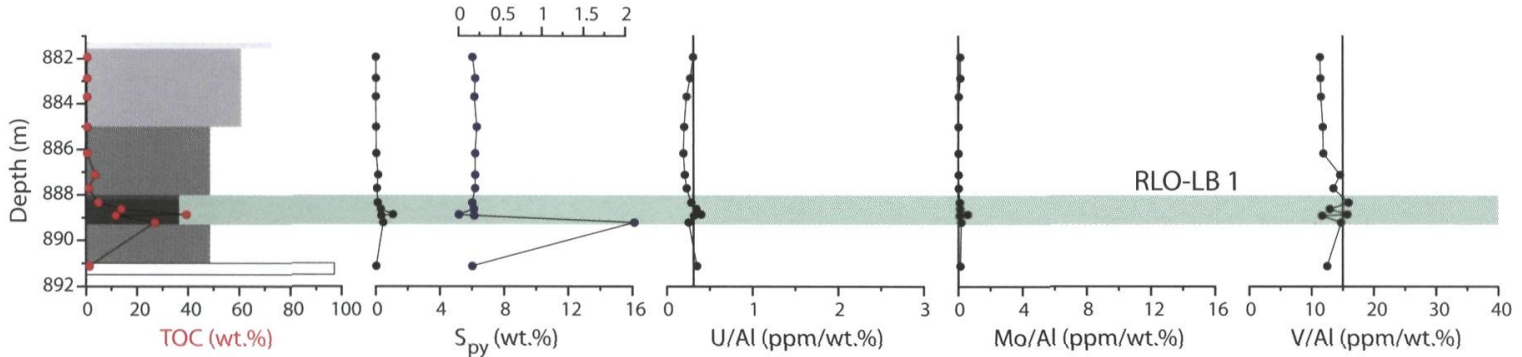

TOC (wt.\%)

$\mathrm{C}_{\text {carb. }}$ (wt.\%)
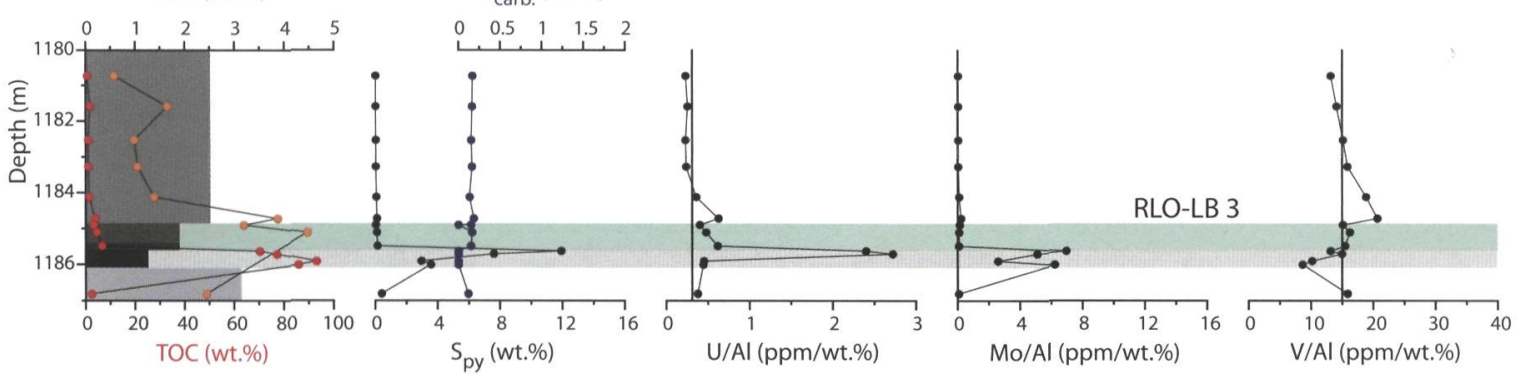

\begin{tabular}{ll|}
\hline Legend & Lithology \\
$\square$ Marine band & $\square$ Sandstone \\
$\square$ Lacustrine band \\
Siltsy claystone \\
$\square$ Coal & $\square$ Clayey siltstone \\
Claystone & Claystone - high C
\end{tabular}

Fig. 5. Plots of two Lingula marine bands, two lacustrine bands and the Goniatites marine band to show the distribution of TOC, S, $C_{\text {carbonate }}$ and a selection of trace metals. Note the different scales used for TOC. In this figure the Al-normalised values for coal are shown. Note that the enrichment factors for coal displayed in figure 6 has been calculated in a different way. The coal-values in this figure are probably slightly over-estimated (see Methods). 

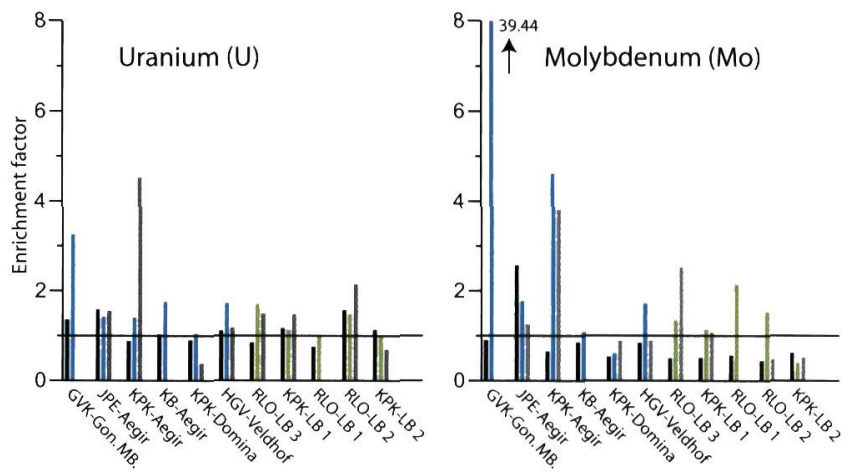

In the Lingula marine bands KPK-Aegir, JPE-Aegir, HGV-Veldhof, enhanced S contents (up to $5.52 \mathrm{wt} \%$ in JPE-Aegir) occur in the basal part overlying the coal. In KPK-Domina only one sample shows an enrichment of $>1 \mathrm{wt} \% \mathrm{~S}$, whereas in KB-186 none of the samples from the marine band is $>1 \mathrm{wt} \%$. An upward decrease in pyrite content can in most cases be observed within the marine band (Fig. 5 and Appendix 1), leading to a 'background' value of $\leqslant 0.1 \mathrm{wt} \%$ in the normal shale overlying the Lingula marine bands. The only exception is JPE-Aegir in which pyrite contents remain relatively high ( $\mathrm{S} \geqslant 1.5 \mathrm{wt} \%$ ) throughout the marine band. The Goniatites marine band shows marked enrichments in pyrite (Fig. 5 and Appendix 1). The lacustrine bands are characterised by low $\mathrm{S}$ contents without exception. In RLO-LB 2 a maximum of $0.42 \mathrm{wt} \%$ (of all lacustrine bands) has been measured, which is significantly lower than the $S$ contents in the Lingula marine bands.

The coals located below the Lingula marine bands show even higher sulphur contents than the overlying shale (Fig. 5 and Appendix 1). At the base of the coal below KPK-Aegir, a maximum of $12.4 \mathrm{wt} \% \mathrm{~S}$ has been measured. These sulphur contents are probably related to percolating seawater after the marine flooding, a process well-known from literature (Chou, 1984; Spears et al., 1999). In contrast, the coals below the lacustrine bands does not have strong enrichments in sulphur. The only exception is the RLO-LB 3 coal in which S is present up to $12 \mathrm{wt} \%$. This coal is probably directly influenced by seawater, regarding the lack of $S$ enrichments in the overlying lacustrine shale.

\section{Trace elements}

The Goniatites marine band shows a relatively high mean EF for $U$ and Mo, whereas $V$ is only moderately enriched (Fig. 6). None of the Lingula marine and lacustrine bands shows a mean EF higher than 2 for U, Mo and V; KPK-Aegir and RLO-LB 1 for Mo excluded. Apart from $\mathrm{Pb} / \mathrm{Zn}$ and $\mathrm{Zn}$ in RLO-LB 1 and RLO$\mathrm{LB} 2$ respectively, in general the EFs for $\mathrm{Cu}, \mathrm{Ni}, \mathrm{Pb}$ and $\mathrm{Zn}$ are very low to insignificant for both the marine and the lacustrine bands (Fig. 6). Some sections do not show enrichments and even depletions relative to the average shale can be seen. The highest EF of U, Mo and V do not occur in the Lingula marine bands but in some of the underlying coals instead. This is also applies to some coals underlying the lacustrine bands (Fig. 6). An example is the coal located below the Aegir marine band in $\mathrm{KPK}-1$. In the topmost sample in the coal a $30 \mathrm{ppm}$ concentration for U was obtained, which clearly corresponds with the peak in the spectral gamma-ray at that depth (Fig. 1).

$\mathrm{Th} / \mathrm{U}$ ratios, which are used to distinguish marine bands from normal shale, were obtained for all marine and lacustrine bands (Fig. 7). Davies \& McLean (1996) considered Th/U ratios lower than 3.8 diagnostic for marine bands whereas Adams \&
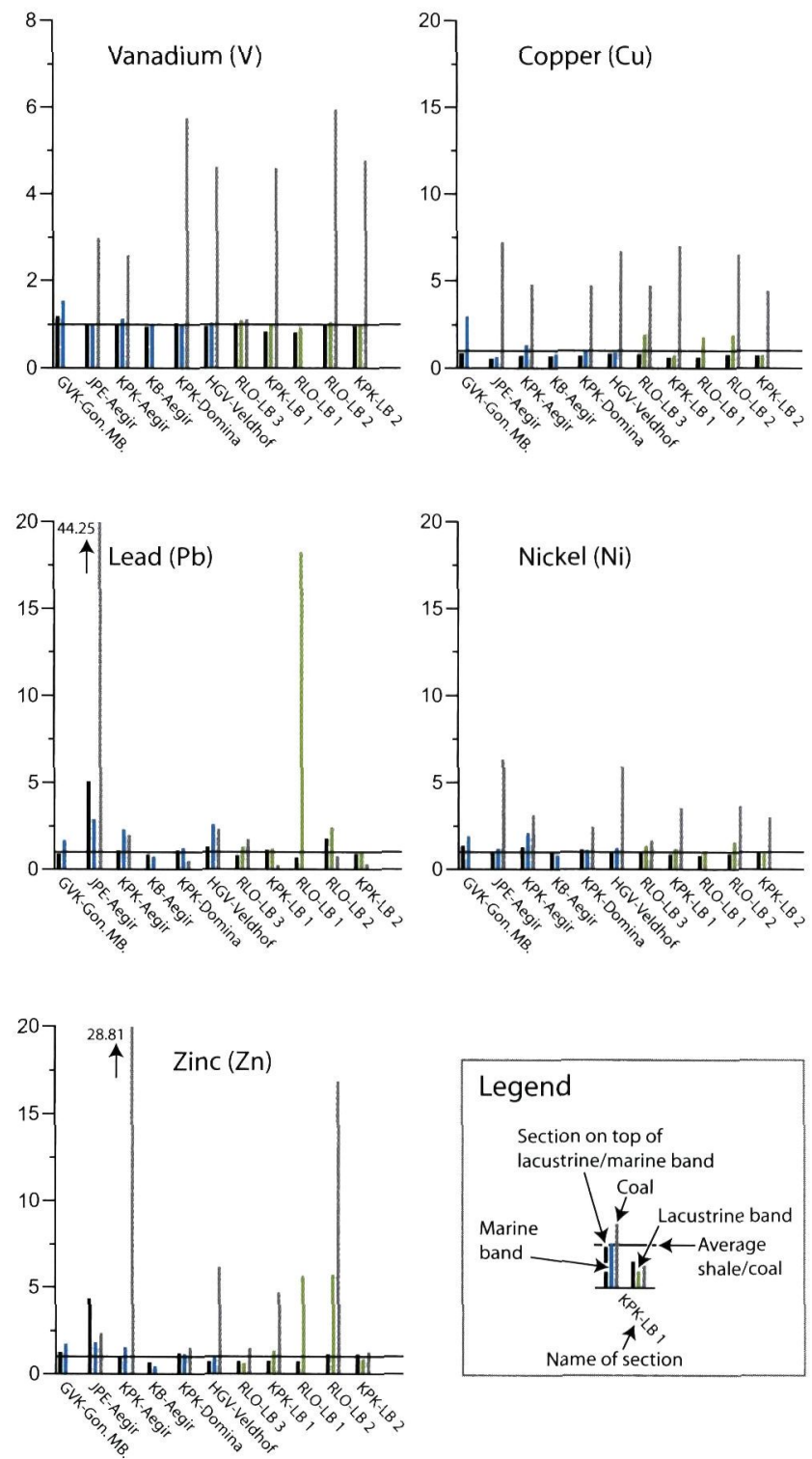

Fig. 6. Bar charts displaying the enrichments factors for the marine/ lacustrine bands, the underlying coal and the overlying sediments. It is important to realise that the enrichment factors for the coals have been calculated differently (see text). Therefore, an enrichment of a certain element in a coal (for instance vanadium) does not necessarily means that the absolute concentrations are higher in the coal than in the under and overlying sediments (see Appendix 1). 
Weaver (1958), used by Hollywood \& Whorlow (1993), thought a ratio lower than 2 representative for fully marine conditions. This figure again shows that the Lingula marine bands display the same order of $U$ enrichments as the lacustrine bands whereas the Goniatites marine band is the only one clearly enriched.

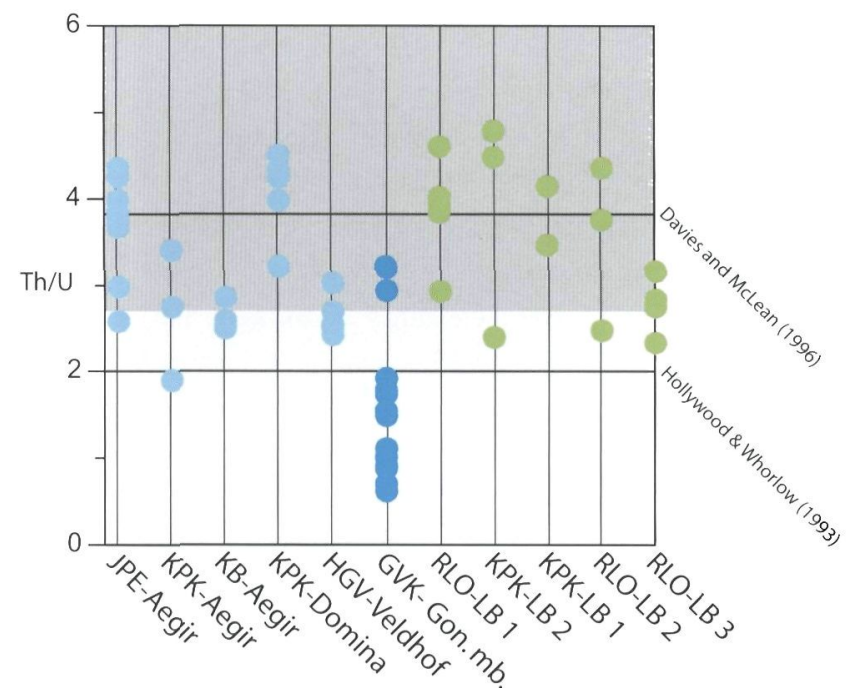

Fig. 7. Th/U ratios for marine and lacustrine bands. The grey box indicates the area where the $T h / U$ ratios plot derived from the sediments overlying the marine and lacustrine bands. It can be seen that only the Goniatites marine band (dark blue) clearly displays an enrichment in U. The Lingula marine (light blue) and lacustrine bands (green) display minor or no enrichment in $U$ compared to the overlying sediments.

\section{Discussion}

The data suggest that the Lingula marine bands have a low organic carbon content compared to the Goniatites marine band and the lacustrine bands. Pyrite contents are, however, clearly enriched in most Lingula bands which set them apart from the lacustrine bands. Trace element enrichment in the Lingula and lacustrine bands is low and often absent, in contrast to the Goniatites marine band investigated here and reported in literature (Bloxham \& Thomas, 1969; Fisher \& Wignall, 2001). Although it has to be realised that the enrichment factors in Fig. 6 are mean values and that individual samples sometimes have higher enrichment factors, the mean EFs for the Lingula marine bands are considered to be insignificant. They are comparable to the EFs obtained for the sediments overlying the marine bands. Moreover, in general EFs are far higher (3.5 200 times) in marine bands/black shale reported in literature (Coveney et al., 1991; Fisher \& Wignall, 2001, their table 1; Algeo \& Maynard, 2004; Cruse \& Lyons, 2004). Therefore, the Lingula marine bands can not be easily distinguished using the $\mathrm{Th} / \mathrm{U}$ ratio alone. To effectively find marine bands on the basis of the Th/U ratios the ratio defined by Hollywood \& Whorlow (1993) should be used. The ratio defined by Davies \& McLean (1996) is not diagnostic because numerous samples derived from floodplain sediments fall into the marine bands-field.
Based on the results obtained here and those reported in literature, i.e. the clear enrichment of $U$ in Goniatites marine bands and the absence in Lingula marine bands, recognition of marine bands using the gamma-ray log is only promising when they are found in Goniatites facies. Since the Lingula marine bands mainly occur along the basin margins, in these areas recognition of marine bands using gamma-ray only would be complicated. Although the dataset is limited, it might be concluded that the southern part of the Netherlands and Belgium did not belong to the main depocentre during Westphalian $\mathrm{B} / \mathrm{C}$.

In addition, the following questions remain to be answered: 1) what determines the TOC in the Lingula/Goniatites marine bands and the lacustrine bands; 2) why such poor trace element EFs in the Lingula marine and 3) lacustrine bands; 4) why are the trace element EFs in the coals mostly higher than in the overlying marine/lacustrine bands and 5) are the EFs synsedimentary or diagenetic?

Ad 1. Ramsbottom (1969) observed that although the total succession (of, for instance the Westphalian A) thins towards the basin margins, the individual marine horizons are thicker when benthonic fossils are present (like the Lingula marine bands) than when they only contain Goniatites. Therefore, the siliciclastic sedimentation rate in the Goniatites-bearing intervals is probably lower than in the Lingula marine bands. A relatively high siliciclastic sedimentation rate, together with the absence of anoxic bottom water conditions (thus causing enhanced oxidation and dilution of organic matter) probably lead to lower TOC in the Lingula bands. A comparable situation was observed in Mediterranean sapropels, which tend to become thicker and therefore show 'diluted' TOC towards the Nile delta (ten Haven et al., 1987). The higher TOC of the lacustrine bands probably has to be explained by a combination of a rather slow sedimentation rate plus a high influx of (non-degradable) organic matter.

Ad 2. Algeo \& Maynard (2004) found that the trace elements U, Mo, $\mathrm{V}, \mathrm{Zn}$ and $\mathrm{Pb}$ show strong enrichments under euxinic (>10 wt $\%$ TOC) circumstances, forming complexes with sulphides preferentially. During anoxic (TOC $<10 \mathrm{wt} \%$, non-sulphidic) conditions these TEs show a strong correlation with TOC, but the EF remain rather limited. In this light, the original TOC values of the Goniatites marine band (up to 10\%) are in accordance with the higher trace element EFs. In the Lingula marine bands, TOC concentrations do not even exceed $5 \mathrm{wt} \%$. This suggests that at the most, anoxic and no euxinic conditions prevailed during deposition of the marine bands, which forms an explanation for the small enrichment of trace elements in the sections studied here. The presence of Lingulas (brachiopods) already suggests that the oxygen concentration in the bottom waters is not too low to prevent these animals to live there. In addition, Bloxham \& Thomas (1969) and Fisher \& Wignall (2001) 
concluded that $U$ is concentrated in the most organic rich parts of marine bands. Another explanation for the poor trace element enrichment may be a brief period of oxygenation which leads to the dissolution of scavenged elements (Anderson et al., 1989).

Ad 3. Trace elements can also be enriched in organic-rich fresh water sediments (Elbaz-Poulichet et al., 1997; Fisher \& Wignall, 2001). However, it has to be realised that the concentrations of $U$ and Mo in fresh water are much lower than in seawater (Taylor \& McLennan, 1985) which probably means that anoxic conditions have to be more prolonged than in marine anoxic environments. Although the TOC contents of the lacustrine bands are in general much higher than the Lingula marine bands, the strongly limited availability of these trace elements prevents a significant enrichment.

Ad 4. Mo and U show higher EFs in the coals located below two of the Lingula marine bands than observed in the coals below the lacustrine bands (Fig. 6). Although it does not apply to all coals below the Lingula marine bands, it is suggested here that the influence of percolating seawater may lead to enhanced enrichments of $U$ and Mo in the underlying coal. An example of this phenomenon is the $U$ peak in the coal located below the Aegir marine band in the well KPK-1. The same process is probably responsible for the enrichment of Mo in the RLO-LB 3 coal, which also showed marine influence through its high sulphur contents. This is in accordance with the study of Gayer et al. (1999) who also found higher U and Mo contents in marine influenced coal than in coal overlain by lacustrine deposits. However, independent of the composition of the overlying sediment, coal tends to act as traps for migrating trace elements (Laznicka, 1985). It is therefore suggested that the enrichment of $\mathrm{Ni}, \mathrm{Pb}, \mathrm{Zn}$ and $\mathrm{Cu}$ as observed in the coals is mainly due to diagenetic processes because there is no preferential enrichment of these metals for marine or lacustrine influenced coal (Fig. 6). Late diagenetic enrichment of these metals was also interpreted by Dill \& Pöhlmann (2002) in their study on Carboniferous coals in the Ruhr Basin. Uranium can also be diagenetically enriched. Jedwab (1966) reported a late-diagenetic enrichment of uranium in coal intercalated in a sequence of lacustrine black shale whereas Davidson \& Ponsford (1954) concluded that uranium enrichments in coal were caused by percolating meteoric waters. Nekrasova (1957) also concluded that the permeability and reducing conditions in Jurassic coal caused the diagenetic enrichment of $U$. The observation (in this study) that U mainly occurs in coal that experienced marine influence, does not prove that this is the only way to get enrichment but rather the absence of other mechanisms or sources.

Ad 5. Most authors imply that enrichment of trace elements in marine bands/black shale took place syn-genetically by scavenging of trace elements by organic matter or Fesulphides (Bloxham \& Thomas, 1969; Fisher \& Wignall, 2001; Algeo \& Maynard, 2004). However, Laznicka (1985) attributed enrichment of trace elements on top of coals (where the marine bands are found) to late diagenetic processes. Realising that iron ore formation together with the associated enrichment in trace elements frequently took place above coal seams in the Carboniferous (Laznicka, 1985), this clearly leaves the possibility for a diagenetic enrichment of iron-sulfide and associated trace elements. Although the EFs in the lacustrine and Lingula marine bands are very low, such a process cannot be ruled out as the highest enrichments consequently takes place just on top of the coal seam.

\section{Conclusions}

Lingula and Goniatites marine bands can be distinguished in the Upper Carboniferous fluvio-lacustrine sedimentary sequence of the Netherlands and surrounding areas (Calver, 1969; Ramsbottom, 1969). Lingula bands formed in a nearshore environment whereas Goniatites marine bands are characterised by a deeper marine setting. The marine bands show a marked difference in enrichment of redox-sensitive trace elements such as $U$ and Mo. The geochemical characteristics of both marine band types were analysed. Lacustrine bands were also investigated because these show the same sedimentological characteristics as the Lingula marine bands. These depositional environments show a typical set of geochemical characteristics (Fig. 8), which will be explained shortly.

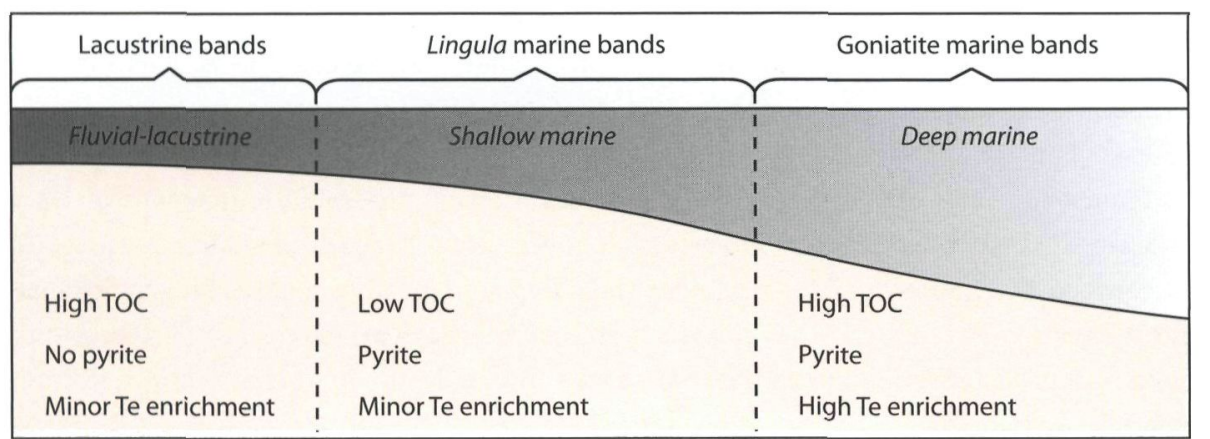

Fig. 8. Schematic cross-section displaying the areal distribution and geochemical characteristics of the intervals studied in this paper. TOC: total organic carbon; Te: trace elements. 
The Goniatites marine band displays high TOC (up to $10 \mathrm{wt} \%$ ), sulphur and redox sensitive trace element contents. Therefore, Goniatites marine bands can typically be characterised as marine black shale. Condensed sedimentation under marine and anoxic bottom water conditions lead to the effective scavenging of redox-sensitive trace elements. An important difference between the Goniatites and Lingula marine bands is the much lower TOC contents in the latter $(1-2 \mathrm{wt} \%)$. This is attributed to a relatively high siliciclastic sedimentation rate during marine flooding, leading to dilution. It is proposed that the absence of high TOC concentrations (and possibly the absence of anoxic bottom water conditions) prevented the effective scavenging of trace elements during deposition of Lingula bands. Next to this explanation, a diagenetic process like the migration of an oxidation front or late-diagentic enrichment cannot be ruled out. The lacustrine bands are characterised by high TOC contents but low sulphur and trace element concentrations. The high TOC contents can be explained by a combination of a slow siliciclastic sedimentation rate and a high influx of (non-degradable) organic matter. Enrichment of trace elements and sulphur in the lacustrine bands is absent or moderate. The limited availability of elements like S, U, Mo and $\mathrm{V}$ in fresh water is the most likely explanation.

Based on the results obtained during this study it is proposed that detection of marine bands with a gamma-ray device is only promising when they are developed in Goniatites facies. Along the margins of the basin, where marine bands occur in shallow marine Lingula facies, this method will probably fail.

\section{Acknowledgements}

Michiel Dusar, Rob de Wilde, Rob van Galen and Jan Drenth are thanked for their help collecting and analysing the samples. Harry Veld and Gerard Klaver are gratefully acknowledged for their comments on earlier versions of the manuscript. The reviews from Mark Geluk and Noël Vandenberghe are highly appreciated and significantly improved the final version of the manuscript.

\section{References}

Adams, J.A. \& Weaver, C.E., 1958. Thorium-uranium ratios as indicators of sedimentary processes: example of concept of geochemical facies. Bulletin American Association of Petroleum Geologists 42: 387-430.

Algeo, T.J. \& Maynard, J.B., 2004. Trace-element behavior and redox facies in core shales of Upper Pennsylvanian Kansas-type cyclothems. Chemical Geology 206: 289-318.

Algeo, T.J., Schwark, L. \& Hower, J.C., 2004. High-resolution geochemistry and sequence stratigraphy of the Hushpuckney Shale (Swope Formation, eastern Kansas); implications for climato-environmental dynamics of the Late Pennsylvanian Midcontinent Seaway. Chemical Geology 206: 259-288.
Anderson, R.F., LeHuray, A.P., Fleisher, M.Q. \& Murray, J.W., 1989. Uranium deposition in Saanich Inlet sediments, Vancouver Island. Geochimica et Cosmochimica Acta 53: 2205-2213.

Archard, G. \& Trice, $R$., 1990. A preliminary investigation into the spectral radiation of the Upper Carboniferous marine bands and its stratigraphic application. Newsletters on Stratigraphy 21: 167-173.

Berner, R.A. \& Raiswell, R., 1984. C/S method for distinguishing freshwater from marine sedimentary rocks. Geology 12: 365-368.

Bloxham, T.W. \& Thomas, R.L., 1969. Palaeontological and geochemical facies in the Gastrioceras subcrenatum marine-band and associated rocks from North Crop of the South Wales Coalfield. Quaterly Journal of Geological Society, London 124: 239-281.

Calver, M.A., 1969. Westphalian of Britain. Compte Rendu Congres International de Stratigraphie et de Geologie du Carbonifere 1: 233-254.

Chou, C.L., 1984. Relationship between geochemistry of coal and the nature of strata overlying the Herin Coal in the Illinois Basin, USA. Memoir of the Geological Society of China 6: 269-280.

Coveney, R.M., Jr., Watney, W.L. \& Maples, C.G., 1991. Contrasting depositional models for Pennsylvanian black shale discerned from molybdenum abundances. Geology 19: 147-150.

Cruse, A.M. \& Lyons, T.W., 2004. Trace metal records of regional paleoenvironmental variability in Pennsylvanian (Upper Carboniferous) black shales. Chemical Geology 206: 319-345.

Davidson, C.F. \& Ponsford, D.R.A., 1954. On the occurrence of uranium in coals. Mining Magazine 91: 265-273.

Davies, S.J. \& McLean, D., 1996. Spectral gamma-ray and palynological characterization of Kinderscoutian marine bands in the Namurian of the Pennine Basin. Proceedings of the Yorkshire Geological Society 51: 103-114.

Dellwig, O., 1999. Geochemistry of Holocene coastal deposits (NW Germany): Palaeoenvironmental reconstruction. Carl von 0ssietzky Universität (Oldenburg): $297 \mathrm{pp}$.

Diessel, C.F.K., 1992. Coal-bearing depositional systems. Springer-Verlag (Berlin): $721 \mathrm{pp}$.

Dill, H.G. \& Pöhlmann, H., 2002. Chemical composition and mineral matter of paralic and limnic coal types of lignite through anthracite rank (Germany). Carboniferous and Permian of the world; XIV ICCP Memoir Canadian Society of Petroleum Geologists 19: 851-867.

Drozdzewski, G., 2005. Zur sedimentären Entwicklung des Subvariscikums im Namurium und Westfalium Nordwestdeutschlands. In: Wrede, V. (ed.): Stratigraphie von Deutschland V - Das Oberkarbon (Pennsylvanium) in Deutschland. Cour. Forsch.-Inst. Senckenberg (Frankfurt a. M.) 254: 151-203.

Dusar, M., Paproth, E., Streel, M. \& Bless Martin, J.M., 2000. Palaeogeographic and palaeoenvironmental characteristics of major marine incursions in northwestern Europe during the Westphalian C (Bolsovian). Geologica Belgica 3: 331-347.

Elbaz-Poulichet, F., Nagy, A. \& Cserny, T., 1997. The Distribution of Redox Sensitive Elements (U, As, Sb, V and Mo) along a River-Wetland-Lake System (Balaton Region, Hungary). Aquatic Geochemistry 3: 267-282.

Fisher, Q.J. \& Wignall, P.B., 2001. Palaeoenvironmental controls on the uranium distribution in an Upper Carboniferous black shale (Gastrioceras listeri Marine Band) and associated strata; England. Chemical Geology 175: 605-621. 
Gayer, R.A., Rose, M., Dehmer, J. \& Shao, L.Y., 1999. Impact of sulphur and trace element geochemistry on the utilization of a marine-influenced coal; case study from the South Wales Variscan foreland basin. International Journal of Coal Geology 40: 151-174.

Goodarzi, F. \& Swaine, D.J., 1993. Chalcophile elements in Western Canadian coals. International Journal of Coal Geology 24: 281-292.

Holdsworth, B.K. \& Collinson, J.D., 1988. Millstone Grit cyclicity revisited. In: Besly, B.M. \& Kelling, G. (eds): Sedimentation in a synorogenic basin complex; the Upper Carboniferous of Northwest Europe. Blackie and Son (London): 132-152.

Hollywood, J.M. \& Whorlow, C.V., 1993. Structural development and hydrocarbon occurrence of the Carboniferous in the UK southern North Sea Basin. In: Parker, J.R. (ed.): Petroleum geology of Northwest Europe; Proceedings of the 4th conference. Geological Society (London): 689-696.

Hoogteijling, P.J., 1948. Radioactiviteit en bodemgesteldheid. Vrije Universiteit (Amsterdam): 93 pp.

Jedwab, J., 1966. Les degats radiatifs dans le charbon uranifere du Schaetzel. Geologische Rundschau 55: 445-453.

Krull, P., 2005. Paläogeographischer Rahmen. In: Wrede, V. (ed.): Stratigraphie von Deutschland V - Das Oberkarbon (Pennsylvanium) in Deutschland. Cour. Forsch.-Inst. Senckenberg (Frankfurt a. M.) 254: 3-12.

Laznicka, P., 1985. The geological association of coal and metallic ores - a review. In: Wolf, K.H. (ed.): Handbook of strata-bound and stratiform ore deposits. Regional studies and specific deposits 13: 1-71.

Leeder, M.R., 1988. Recent developments in Carboniferous geology; a critical review with implications for the British Isles and N.W. Europe. Proceedings of the Geologists' Association 99: 73-100.

Leeder, M.R., Raiswell, R., Al Biatty, H., McMahon, A. \& Hardman, M., 1990. Carboniferous stratigraphy, sedimentation and correlation of Well 48/3-3 in the southern North Sea basin; integrated use of palynology, natural gamma/ sonic logs and carbon/sulphur geochemistry. Journal of the Geological Society of London 147: 287-300.

Lyons, T.W., Werne, J.P., Hollander, D.J. \& Murray, R.W., 2003. Contrasting sulfur geochemistry and $\mathrm{Fe} / \mathrm{Al}$ and $\mathrm{Mo} / \mathrm{Al}$ ratios across the last oxic-toanoxic transition in the Cariaco Basin, Venezuela. Chemical Geology 195: 131-157.

Martinsen, O.J., Collinson, J.D. \& Holdsworth, B.K., 1995. Millstone Grit cyclicity revisited; II, Sequence stratigraphy and sedimentary responses to changes of relative sea-level. In: Plint, A.G. (ed.): Sedimentary facies analysis; a tribute to the research and teaching of Harold G. Reading. Special Publication of the International Association of Sedimentologists (0xford) 22: 305-327.

Meessen, J.P.M.T., 1985. Rapport betreffende het onderzoek naar microfossielen van een drietal trajecten van boring Ruurlo 1. Internal report 2085. Rijks Geologische Dienst, Haarlem.

Menning, M., Alekseev, A.S., Chuvashov, B.I., Davydov, V.I., Devuyst, F.X., Forke, H.C., Grunt, T.A., Hance, L., Heckel, P.H., Izokh, N.G., Jin, Y.G., Jones, P.J., Kotlyar, G.V., Kozur, H.W., Nemyrovska, T.I., Schneider, J.W., Wang, X.D., Weddige, K., Weyer, D. \& Work, D.M., 2006. Global time scale and regional stratigraphic reference scales of central and west Europe, east Europe, Tethys, south China, and North America as used in the DevonianCarboniferous-Permian Correlation Chart 2003 (DCP 2003). Palaeogeography, Palaeoclimatology, Palaeoecology 240: 318-372.
Nekrasova, Z.A., 1957. K voprosu o genezise uranovogo orudeneniya v uglyakh. Voprosy Geol. Urana 6: 37-54.

Paproth, E., 1989. Die paläogeographische Entwicklung Mittel-Europas im Karbon. Geologisches Jahrbuch Hessen 117: 53-68.

Paproth, E., Dusar, M., Bless, M.J.M., Bouckaert, J., Delmer, A., FaironDemaret, M., Houlleberghs, E., Laloux, M., Pierart, P., Somers, Y., Streel, M., Thorez, J. \& Tricot, J., 1983. Bio- and lithostratigraphic subdivisions of the Silesian in Belgium; a review. Annales de la Societe Geologique de Belgique 106: 241-283.

Rabitz, A., 1966. Die marinen Horizonte des flözführenden Ruhrkarbons. Fortschr. Geol. Rheinld. u. Westf 13: 243-296.

Raiswell, R. \& Berner, R.A., 1987. Organic carbon losses during burial and thermal maturation of normal marine shales. Geology 15: 853-856.

Ramsbottom, W.H.C., 1969. The Namurian of Britain. Compte Rendu Congres International de Stratigraphie et de Geologie du Carbonifere 1: 219-232.

Ramsbottom, W.H.C., Ridd, M.F. \& Read, W.A., 1979. Rates of transgression and regression in the Carboniferous of NW Europe; with discussion and reply. Journal of the Geological Society of London 136: 147-154.

Schultz, R.B., 2004. Geochemical relationships of late Paleozoic carbon-rich shales of the Midcontinent, USA; a compendium of results advocating changeable geochemical conditions.; Geochemistry of organic-rich shales; new perspectives. Chemical Geology 206: 347-372.

Spears, D.A., 1964. The major element geochemistry of the Mansfield marine band in the Westphalian of Yorkshire. Geochimica et Cosmochimica Acta 28: 1679-1696.

Spears, D.A., Rippon, J.H. \& Cavender, P.F., 1999. Geological controls on the sulphur distribution in British Carboniferous coals; a review and reappraisal. International Journal of Coal Geology 40: 59-81.

Spears, D.A. \& Sezgin, H.I., 1985. Mineralogy and geochemistry of the Subcrenatum Marine Band and associated coal-bearing sediments, Langsett, South Yorkshire. Journal of Sedimentary Petrology 55: 570-578.

Swaine, D.J., 1990. Trace elements in coal. Butterworth (London): 278 pp.

Taylor, S.R. \& McLennan, S.M., 1985. The continental crust: its composition and evolution. Blackwell (0xford): $312 \mathrm{pp}$.

Ten Haven, H.L., Baas, M., de Leeuw, J.W., Schenck, P.A. \& Brinkhuis, H., 1987. Late Quaternary Mediterranean sapropels; II, Organic geochemistry and palynology of $\mathrm{S}$ (sub 1 ) sapropels and associated sediments. Chemical Geology 64: 149-167.

Thiadens, A.A., 1963. The Palaeozoic of the Netherlands. KNGMG (Delft): 28 pp. Van Amerom, H.W.J. \& Glerum, J.J., 1984. Rapport betreffende de stratigrafische interpretatie van diepboring Kemperkoul-1 op grond van de makroflora. Internal report 2003. Rijks Geologische Dienst, Haarlem.

Van Amerom, H.W.J. \& Meessen, J.P.M.T., 1985. Rapport over mariene niveaus in diepboring Hengevelde-1. Internal report 2094. Rijks Geologische Dienst, Haarlem.

Van Amerom, H.W.J., Meessen, J.P.M.T. \& Glerum, J.J., 1985. Rapport over mariene niveaus in diepboring Joppe-1. Internal report 2091. Rijks Geologische Dienst, Haarlem.

Wignall, P.B., 1994. Black shales. Oxford University Press (0xford): 127 pp.

Ziegler, P.A., 1990. Geological Atlas of Western and Central Europe (2nd edition). Shell Internationale Petroleum Maatschappij B.V.; Geological Society Publishing House (Bath): 239 pp. 


\section{Appendix 1}

\begin{tabular}{|c|c|c|c|c|c|c|c|c|c|c|c|c|c|c|c|}
\hline & \multirow{2}{*}{ Depth } & \multicolumn{3}{|c|}{$\mathrm{C} / \mathrm{S}$} & & r elem & nts $(w$ & & & & Trac & eleme & ts (ppn & & \\
\hline & & TC (\%) & TS (\%) & TOC (\%) & $\mathbf{A l}$ & $\mathrm{Fe}$ & $\mathrm{Ca}$ & $\mathbf{K}$ & $\mathbf{U}$ & Mo & V & $\mathrm{Cu}$ & $\mathbf{N i}$ & $\mathbf{P b}$ & $\mathrm{Zn}$ \\
\hline & 852.39 & 1.1 & 0.3 & 1.0 & 10.1 & 4.0 & 0.2 & 3.0 & 4.7 & 0.5 & 195.4 & 37.8 & 77.5 & 9.4 & 89.7 \\
\hline & 853.81. & 1.3 & 0.3 & 1.2 & 9.0 & 4.8 & 0.3 & 2.5 & 4.5 & 0.4 & 194.0 & 43.2 & 87.5 & 12.8 & 134.0 \\
\hline & 855.67 & 1.1 & 0.5 & 1.0 & 9.7 & 4.2 & 0.2 & 2.8 & 4.8 & 0.5 & 197.2 & 45.0 & 79.6 & 10.5 & 127.0 \\
\hline & 857.63 & 1.1 & 1.2 & 1.1 & 9.8 & 4.8 & 0.2 & 2.9 & 3.7 & 0.8 & 159.4 & 35.2 & 62.5 & 15.9 & 80.1 \\
\hline & 859.72 & 0.8 & 2.2 & 0.8 & 9.8 & 5.1 & 0.2 & 3.0 & 3.0 & 2.6 & 155.7 & 48.2 & 69.9 & 38.8 & 97.5 \\
\hline & 861.80 & 0.9 & 1.4 & 0.9 & 9.1 & 4.7 & 0.3 & 2.7 & 3.3 & 0.8 & 144.6 & 33.2 & 69.3 & 21.8 & 94.8 \\
\hline & 863.66 & 1.0 & 0.7 & 0.9 & 10.3 & 4.6 & 0.3 & 3.1 & 4.5 & 0.6 & 165.4 & 38.5 & 63.6 & 11.2 & 89.8 \\
\hline & 865.62 & 3.5 & 3.4 & 3.0 & 8.9 & 5.7 & 1.5 & 2.8 & 7.9 & 22.9 & 180.1 & 135.7 & 94.5 & 61.8 & 79.8 \\
\hline हि & 867.76 & 1.7 & 2.3 & 1.5 & 10.0 & 5.3 & 0.6 & 3.1 & 3.8 & 4.3 & 179.5 & 61.7 & 75.2 & 32.3 & 107.1 \\
\hline Бี & 869.56 & 1.1 & 2.0 & 1.0 & 10.8 & 5.2 & 0.3 & 3.3 & 4.4 & 7.7 & 171.3 & 42.1 & 74.7 & 20.3 & 92.6 \\
\hline i & 871.72 & 4.7 & 3.4 & 4.0 & 8.1 & 5.3 & 2.1 & 2.5 & 11.4 & 46.4 & 204.7 & 172.5 & 103.6 & 27.2 & 108.9 \\
\hline 总 & 873.63 & 2.3 & 3.5 & 2.1 & 9.3 & 5.0 & 0.7 & 2.9 & 6.1 & 5.7 & 186.2 & 112.9 & 84.8 & 25.4 & 119.3 \\
\hline & 875.63 & 5.0 & 2.8 & 3.6 & 4.8 & 3.7 & 4.5 & 1.5 & 7.3 & 59.0 & 173.6 & 138.5 & 91.5 & 18.0 & 105.9 \\
\hline & 877.73 & 5.3 & 3.1 & 3.6 & 6.6 & 5.5 & 5.8 & 1.9 & 9.4 & 63.0 & 149.6 & 146.6 & 77.5 & 19.7 & 115.8 \\
\hline & 881.67 & $\begin{array}{l}5.0 \\
5.0\end{array}$ & $\begin{array}{l}4.3 \\
2.8\end{array}$ & $\begin{array}{l}4.9 \\
3.7\end{array}$ & $\begin{array}{l}1.0 \\
5.0\end{array}$ & $\begin{array}{l}0.2 \\
4.2\end{array}$ & $\begin{array}{l}3.6 \\
4.0\end{array}$ & 2.5 & 10.0 & 59.0 & $\begin{array}{c}108.4 \\
162.7\end{array}$ & $\begin{array}{l}170.5 \\
134 ?\end{array}$ & $\begin{array}{l}89.3 \\
87.9\end{array}$ & 22.1 & 126.4 \\
\hline & 883.84. & 2.0 & 2.5 & 1.8 & 10.0 & 4.2 & 0.6 & 3.1 & 6.9 & 5.3 & 225.7 & 76.6 & 78.8 & 19.8 & 129.1 \\
\hline & 885.02 & 1.3 & 1.6 & 1.0 & 11.4 & 4.8 & 0.9 & 3.4 & 4.2 & 1.3 & 198.1 & 48.8 & 74.7 & 21.6 & 122.0 \\
\hline & 886.74 & 1.8 & 2.9 & 1.7 & 10.6 & 5.2 & 0.3 & 3.2 & 7.4 & 7.2 & 214.6 & 74.8 & 79.4 & 22.7 & 138.8 \\
\hline & 888.54 & 4.1 & 3.6 & 3.6 & 8.2 & 5.3 & 1.5 & 2.4 & 9.6 & 23.3 & 238.3 & 183.6 & 85.4 & 42.3 & 190.1 \\
\hline & 890.55 & 1.8 & 3.1 & 1.7 & 10.0 & 4.6 & 0.3 & 3.1 & 7.7 & 6.6 & 243.3 & 100.8 & 83.4 & 39.5 & 156.4 \\
\hline & 1118.93 & 1.0 & 1.2 & 0.9 & 5.4 & 3.5 & 0.3 & 1.8 & 2.8 & 1.5 & 82.1 & 22.1 & 34.6 & 70.8 & 178.7 \\
\hline & 1120.26 & 1.8 & 1.2 & 1.7 & 6.9 & 4.8 & 0.4 & 2.4 & 3.2 & 1.7 & 104.2 & 8.4 & 32.7 & 49.8 & 283.8 \\
\hline & 1121.59 & nd & nd & nd & nd & nd & nd & nd & 3.3 & 1.6 & 117.7 & 21.7 & 54.2 & 61.2 & 159.5 \\
\hline & 1123.04 & 1.9 & 1.3 & 1.8 & 8.0 & 5.8 & 0.4 & 2.9 & 3.0 & 1.2 & 128.4 & 18.4 & 49.0 & 64.9 & 224.0 \\
\hline & 1124.32 & nd & nd & nd & nd & nd & nd & nd & 4.1 & 1.2 & 127.7 & 22.6 & 42.6 & 79.3 & 221.9 \\
\hline & 1124.73 & nd & nd & nd & nd & nd & nd & nd & 4.3 & 1.3 & 129.1 & 21.5 & 49.8 & 54.4 & 286.6 \\
\hline & 1125.24 & nd & nd & nd & nd & nd & nd & nd & 4.3 & 1.5 & 140.2 & 27.5 & 56.1 & 59.4 & 221.1 \\
\hline 岁 & 1126.03 & 1.7 & 1.4 & 1.7 & 10.4 & 4.8 & 0.3 & 3.4 & 4.3 & 2.3 & 147.0 & 30.9 & 59.4 & 50.7 & 291.5 \\
\hline ब्ष & 1126.56 & nd & nd & nd & nd & nd & nd & nd & 4.0 & 1.1 & 133.9 & 23.7 & 58.3 & 48.5 & 226.4 \\
\hline 㤐 & 1127.23 & nd & nd & nd & nd & nd & nd & nd & 4.0 & 1.2 & 146.5 & 26.7 & 49.0 & 66.0 & 210.7 \\
\hline & 1129.10 & 2.6 & 0.2 & 2.4 & 9.6 & 10.1 & 0.5 & 3.1 & 3.1 & 1.3 & 178.8 & 23.2 & 40.1 & 31.2 & 83.0 \\
\hline & 1129.86 & 0.3 & 0.4 & 0.2 & 12.1 & 3.0 & 0.2 & 4.1 & 4.7 & 0.8 & 180.5 & 39.5 & 51.6 & 56.0 & 97.7 \\
\hline & 1130.31 & 1.6 & 1.6 & 1.6 & 10.1 & 4.1 & 0.2 & 3.1 & 6.5 & 3.9 & 132.4 & 34.8 & 69.1 & 53.9 & 159.7 \\
\hline & 1130.79 & 1.7 & 5.5 & 1.6 & 9.9 & 7.6 & 0.2 & 3.0 & 4.9 & 1.1 & 128.7 & 54.3 & 131.0 & 86.7 & 50.8 \\
\hline & 1130.99 & 80.5 & 6.5 & 80.5 & & & & & 3.1 & 5.1 & 57.3 & 51.3 & 82.7 & 2611.3 & 47.7 \\
\hline & 1131.05 & 0.6 & 2.5 & 0.6 & 11.4 & 4.9 & 0.1 & 3.6 & 5.0 & 2.0 & 135.6 & 25.1 & 59.7 & 58.0 & 48.1 \\
\hline & 1131.50 & 0.9 & 0.9 & 0.6 & 10.9 & 4.0 & 0.9 & 3.8 & 5.6 & 0.8 & 166.7 & 29.0 & 52.6 & 228.6 & 166.9 \\
\hline & 1131.90 & 83.2 & 1.2 & 83.2 & 3.6 & nd & nd & nd & 10.2 & 0.9 & 49.6 & 45.1 & 67.5 & 891.7 & 80.8 \\
\hline & 1192.41 & nd & nd & nd & nd & nd & nd & nd & 2.7 & 0.6 & 145.6 & 26.6 & 63.2 & 15.8 & 99.9 \\
\hline & 1203.18 & nd & nd & nd & nd & nd & nd & nd & 3.0 & 0.5 & 154.2 & 34.4 & 53.7 & 23.2 & 142.9 \\
\hline & 1213.33 & 1.1 & 0.1 & 1.1 & 11.0 & 3.5 & 0.3 & 3.5 & 3.1 & 0.7 & 162.2 & 32.1 & 73.4 & 23.4 & 120.5 \\
\hline & 1217.04 & 1.6 & 0.1 & 1.4 & 9.9 & 4.4 & 0.4 & 3.0 & 2.9 & 0.6 & 147.9 & 29.7 & 64.2 & 17.3 & 87.6 \\
\hline & 1219.95 & 0.8 & 0.1 & 0.7 & 11.9 & 2.8 & 0.2 & 3.7 & 3.0 & 0.7 & 170.9 & 34.9 & 81.4 & 27.9 & 91.4 \\
\hline & 1222.00 & 0.8 & 0.0 & 0.8 & 11.9 & 2.8 & 0.2 & 3.9 & 3.0 & 1.0 & 176.4 & 35.8 & 91.7 & 22.3 & 88.7 \\
\hline & 1223.93 & 1.0 & 0.0 & 0.9 & 12.6 & 3.0 & 0.2 & 4.2 & 3.2 & 0.7 & 176.7 & 40.2 & 60.4 & 34.0 & 66.1 \\
\hline "⿹ & 1225.50 & 1.9 & 0.4 & 1.5 & 11.6 & 3.7 & 1.3 & 3.7 & 3.5 & 0.8 & 185.8 & 72.7 & 115.7 & 29.2 & 83.0 \\
\hline$\underset{1}{\longleftarrow}$ & 1226.44 & 2.9 & 2.7 & 2.8 & 11.2 & 4.9 & 0.3 & 3.6 & 5.1 & 8.8 & 202.4 & 94.0 & 134.7 & 48.2 & 133.4 \\
\hline 产 & 1226.5 & nd & nd & nd & nd & nd & nd & nd & 6.8 & 4.4 & 225.7 & 86.7 & 128.5 & 44.7 & 159.8 \\
\hline & 1227.23 & 1.9 & 1.9 & 1.5 & 10.9 & 4.2 & 1.4 & 3.3 & 4.6 & 1.5 & 178.2 & 58.0 & 125.4 & 55.1 & 160.3 \\
\hline & 1227.75 & 79.0 & 7.2 & 79.0 & nd & nd & nd & nd & 31.1 & 48.3 & 70.1 & 34.0 & 26.0 & 35.2 & 182.2 \\
\hline & 1227.99 & 26.8 & 7.0 & 26.8 & nd & nd & nd & nd & 3.7 & 6.0 & 109.9 & 52.3 & 78.6 & 188.2 & 706.6 \\
\hline & 1228.21 & 88.7 & 3.8 & 88.7 & nd & nd & nd & nd & 1.1 & 3.9 & 10.4 & 18.9 & 18.6 & 31.6 & 120.1 \\
\hline & 1228.57 & 71.6 & 12.4 & 71.6 & nd & nd & nd & nd & 0.3 & 3.1 & 7.2 & 30.2 & 42.1 & 223.3 & 1295.8 \\
\hline & 1229.99 & 1.4 & 0.6 & 1.3 & 9.9 & 3.2 & 0.4 & 2.8 & 3.2 & 0.9 & 161.9 & 33.3 & 62.9 & 25.1 & 181.9 \\
\hline & 1250.28 & nd & nd & nd & nd & nd & nd & nd & 2.7 & 0.3 & 145.6 & 29.1 & 43.8 & 17.1 & 83.1 \\
\hline & 1296.5 & 1.1 & 0.1 & 1.0 & 9.9 & 4.3 & 0.2 & 3.3 & 2.8 & 1.0 & 156.4 & 40.9 & 68.6 & 15.9 & 91.5 \\
\hline & 1297.7. & 1.2 & 0.1 & 1.1 & 9.9 & 4.6 & 0.2 & 3.3 & 2.8 & 0.6 & 147.5 & 33.8 & 58.8 & 16.3 & 55.6 \\
\hline & 1298.7 & 0.9 & 0.0 & 0.8 & 11.2 & 3.8 & 0.2 & 3.8 & 3.1 & 0.8 & 161.5 & 36.5 & 70.1 & 31.9 & 50.9 \\
\hline 雪 & 1299.9 & 1.2 & 0.1 & 1.2 & 11.0 & 3.4 & 0.2 & 3.1 & 4.2 & 1.0 & 139.9 & 36.2 & 55.7 & 10.7 & 57.5 \\
\hline 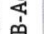 & 1300.7 & 0.9 & 0.1 & 0.9 & 11.5 & 3.4 & 0.2 & 3.5 & 4.5 & 1.2 & 153.0 & 35.3 & 55.6 & 17.7 & 52.7 \\
\hline 罖 & 1301.1 & 1.3 & 0.1 & 1.3 & 12.0 & 4.9 & 0.3 & 3.7 & 6.0 & 0.9 & 186.6 & 45.4 & 53.9 & 16.0 & 46.1 \\
\hline & 1301.8 & 0.9 & 0.3 & 0.8 & 11.9 & 3.4 & 0.3 & 3.6 & 6.6 & 0.9 & 162.3 & 35.5 & 47.4 & 15.3 & 49.1 \\
\hline & 1302.1 & 0.9 & 0.3 & 0.8 & 11.7 & 2.9 & 0.1 & 3.9 & 6.5 & 1.5 & 173.5 & 50.2 & 53.8 & 17.4 & 47.1 \\
\hline & 1302.5 & 0.9 & 0.4 & 0.8 & 11.6 & 3.0 & 0.1 & 4.0 & 6.6 & 1.9 & 180.8 & 61.3 & 60.7 & 23.0 & 45.5 \\
\hline & 1239.80 & 1.2 & 0.1 & 1.1 & 12.6 & 2.5 & 0.3 & 4.3 & 4.6 & 1.7 & 178.8 & 46.7 & 96.3 & 28.8 & 67.1 \\
\hline & 1240.35 & 1.5 & 0.1 & 1.4 & 11.7 & 3.4 & 0.2 & 3.9 & 4.1 & 0.7 & 175.2 & 49.6 & 47.7 & 27.8 & 58.2 \\
\hline & 1240.83 & 1.7 & 0.1 & 1.7 & 11.1 & 3.7 & 0.2 & 3.9 & 3.7 & 0.9 & 168.1 & 48.2 & 72.9 & 29.6 & 79.0 \\
\hline & 1241.27 & 1.1 & 0.1 & 1.0 & 12.7 & 2.7 & 0.2 & 3.9 & 4.1 & 0.9 & 167.9 & 47.2 & 49.6 & 40.3 & 90.4 \\
\hline & 1241.73 & 0.8 & 1.5 & 0.7 & 11.5 & 3.3 & 0.1 & 3.5 & 5.3 & 0.7 & 189.7 & 51.4 & 60.6 & 64.3 & 145.9 \\
\hline 蛋 & 1242.00 & 1.7 & 1.0 & 1.6 & 11.0 & 4.5 & 0.2 & 3.3 & 5.6 & 0.8 & 179.2 & 49.9 & 53.6 & 42.5 & 155.8 \\
\hline 5 & 1242.26 & 1.1 & 2.9 & 1.1 & 11.6 & 4.5 & 0.1 & 3.5 & 6.3 & 2.5 & 184.8 & 47.6 & 80.4 & 45.5 & 51.6 \\
\hline 㕣 & 1242.37 & 1.2 & 4.8 & 1.2 & 11.5 & 6.1 & 0.2 & 3.4 & 6.5 & 4.5 & 163.3 & 47.7 & 99.1 & 65.4 & 44.9 \\
\hline & 1242.50 & 4.6 & 3.6 & 4.6 & 11.0 & 4.9 & 0.2 & 3.2 & 6.4 & 1.5 & 170.3 & 57.9 & 93.0 & 78.0 & 48.5 \\
\hline & 1242.60 & 75.4 & 5.9 & 75.4 & nd & nd & nd & nd & 1.2 & 2.7 & 6.2 & 26.0 & 55.0 & 103.9 & 42.7 \\
\hline & 1242.72 & 72.9 & 5.8 & 72.9 & nd & nd & nd & nd & 3.6 & 4.5 & 169.9 & 68.2 & 100.5 & 174.4 & 205.0 \\
\hline & 1242.79 & 1.5 & 2.4 & 1.4 & 11.1 & 4.2 & 0.2 & 3.6 & 6.9 & 2.1 & 190.9 & 52.0 & 87.6 & 44.5 & 93.9 \\
\hline
\end{tabular}




\begin{tabular}{|c|c|c|c|c|c|c|c|c|c|c|c|c|c|c|c|}
\hline & \multirow{2}{*}{ Depth } & \multicolumn{3}{|c|}{$\mathrm{C} / \mathrm{S}$} & \multicolumn{4}{|c|}{ Major elements ( $w t \%$ ) } & \multicolumn{7}{|c|}{ Trace elements (ppm) } \\
\hline & & TC (\%) & TS (\%) & TOC (\%) & Al & $\mathrm{Fe}$ & $\mathrm{Ca}$ & $\mathbf{K}$ & $\mathbf{U}$ & Mo & v & $\mathrm{Cu}$ & $\mathrm{Ni}$ & $\mathrm{Pb}$ & $\mathrm{Zn}$ \\
\hline \multirow{11}{*}{ 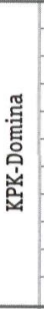 } & 1592.49 & 2.2 & 0.1 & 2.0 & 9.3 & 7.0 & 0.4 & 2.5 & 2.8 & 0.7 & 144.3 & 31.5 & 62.0 & 16.3 & 97.4 \\
\hline & 1593.37 & 1.0 & 0.0 & 1.0 & 11.9 & 3.8 & 0.2 & 3.6 & 3.1 & 0.5 & 178.5 & 41.5 & 69.8 & 26.0 & 121.0 \\
\hline & 1596.00 & 1.1 & 0.0 & 1.1 & 11.8 & 3.9 & 0.2 & 3.6 & 3.2 & 0.5 & 189.0 & 42.0 & 74.0 & 32.6 & 122.0 \\
\hline & 1596.47 & 1.1 & 0.1 & 1.1 & 12.8 & 2.9 & 0.2 & 3.9 & 4.1 & 0.7 & 200.6 & 56.6 & 81.1 & 42.0 & 95.2 \\
\hline & 1596.93 & 1.5 & 0.1 & 1.4 & 12.9 & 2.8 & 0.2 & 3.8 & 4.0 & 0.8 & 180.1 & 49.3 & 93.5 & 35.6 & 130.2 \\
\hline & 1597.1 & nd & nd & nd & nd & nd & nd & nd & 3.5 & 0.4 & 191.5 & 53.7 & 59.8 & 18.9 & 110.1 \\
\hline & 1597.39 & 1.3 & 0.1 & 1.2 & 12.6 & 2.7 & 0.2 & 3.7 & 3.6 & 0.5 & 190.1 & 83.1 & 56.4 & 18.8 & 128.9 \\
\hline & 1597.93 & 1.3 & 1.5 & 1.3 & 12.5 & 3.9 & 0.1 & 3.6 & 4.9 & 1.1 & 195.4 & 60.9 & 86.9 & 32.5 & 153.3 \\
\hline & 1598.12 & 82.8 & 7.5 & 82.8 & nd & nd & nd & nd & 0.8 & 3.6 & 109.6 & 33.4 & 32.4 & 31.7 & 31.3 \\
\hline & 1599.53 & 0.3 & 0.4 & 0.3 & 11.7 & 1.8 & 0.1 & 3.3 & 3.9 & 0.7 & 160.9 & 27.1 & 257.8 & 40.1 & 75.2 \\
\hline & 1601.34 & 1.5 & 0.0 & 1.5 & 9.6 & 4.2 & 0.2 & 2.8 & 2.8 & 0.8 & 137.8 & 32.3 & 58.0 & 16.7 & 98.6 \\
\hline & 1180.73 & 0.6 & 0.0 & 0.6 & 12.1 & 2.9 & 0.1 & 3.4 & 2.8 & 0.4 & 159.1 & 32.0 & 52.3 & 11.6 & 67.6 \\
\hline & 1181.59 & 1.7 & 0.0 & 1.6 & 10.7 & 6.2 & 0.3 & 3.0 & 2.7 & 0.4 & 151.3 & 35.7 & 70.9 & 20.3 & 122.4 \\
\hline & 1182.53 & 1.0 & 0.0 & 1.0 & 12.7 & 3.5 & 0.2 & 3.7 & 2.9 & 0.5 & 192.0 & 40.1 & 72.7 & 17.4 & 76.7 \\
\hline & 1183.27 & 1.1 & 0.0 & 1.1 & 13.2 & 2.7 & 0.2 & 3.9 & 3.1 & 0.6 & 209.4 & 47.6 & 68.0 & 23.0 & 61.0 \\
\hline & 1184.12 & 1.5 & 0.1 & 1.4 & 13.2 & 2.6 & 0.3 & 3.9 & 4.7 & 1.3 & 248.3 & 92.0 & 65.9 & 29.3 & 43.9 \\
\hline & 1184.72 & 3.9 & 0.1 & 3.9 & 12.0 & 1.9 & 0.1 & 3.4 & 7.5 & 2.7 & 248.1 & 163.2 & 98.0 & 47.5 & 9.5 \\
\hline$m$ & 1184.90 & 3.2 & 0.0 & 3.2 & 12.0 & 3.3 & 0.2 & 3.4 & 4.8 & 1.7 & 181.7 & 93.7 & 77.3 & 27.0 & 60.7 \\
\hline ț & 1184.9 & nd & nd & nd & nd & nd & nd & nd & 4.9 & 1.6 & 210.2 & 118.0 & 68.5 & 23.8 & 54.8 \\
\hline & 1185.11 & 4.5 & 0.1 & 4.5 & 12.0 & 2.9 & 0.2 & 3.3 & 5.7 & 1.1 & 194.6 & 116.6 & 83.5 & 30.0 & 57.8 \\
\hline & 1185.49 & 6.8 & 0.1 & 6.6 & 9.7 & 6.7 & 0.4 & 2.3 & 6.0 & 0.8 & 150.2 & 86.4 & 94.2 & 19.8 & 75.6 \\
\hline & 1185.63 & 70.3 & 11.9 & 70.3 & 2.9 & nd & nd & nd & 7.1 & 20.5 & 38.7 & 52.4 & 44.8 & 99.8 & 29.9 \\
\hline & 1185.71 & 77.2 & 7.6 & 77.2 & 1.3 & nd & nd & nd & 3.4 & 6.4 & 18.9 & 26.2 & 10.6 & 220.2 & 30.1 \\
\hline & 1185.91 & 93.1 & 3.0 & 93.1 & 1.6 & nd & nd & nd & 0.7 & 4.1 & 16.2 & 19.0 & 10.4 & 40.5 & 8.6 \\
\hline & 1186.01 & 85.9 & 3.6 & 85.9 & 1.5 & nd & nd & nd & 0.7 & 9.4 & 13.1 & 36.1 & 22.7 & 59.2 & 3.0 \\
\hline & 1186.81 & 2.5 & 0.4 & 2.4 & 7.6 & 2.0 & 0.1 & 2.0 & 2.9 & 0.6 & 120.5 & 33.5 & 43.4 & 17.5 & 7.5 \\
\hline & 1491.65 & 1.6 & 0.0 & 1.5 & 11.3 & 3.8 & 0.2 & 3.0 & 3.9 & 0.5 & 134.2 & 28.9 & 40.5 & 24.1 & 94.0 \\
\hline & 1492.24 & 1.8 & 0.1 & 1.7 & 10.1 & 3.8 & 0.2 & 2.6 & 4.4 & 0.7 & 130.2 & 31.2 & 46.9 & 21.2 & 3.0 \\
\hline & 1493.16 & 0.8 & 0.0 & 0.8 & 12.1 & 2.2 & 0.1 & 3.4 & 4.2 & 0.5 & 142.9 & 27.2 & 50.5 & 22.6 & 75.1 \\
\hline & 1493.98 & 1.8 & 0.0 & 1.7 & 13.0 & 3.7 & 0.2 & 4.1 & 4.2 & 0.7 & 182.2 & 54.4 & 81.6 & 38.6 & 8.5 \\
\hline$\vec{m}$ & 1495.05 & 6.6 & 0.1 & 6.5 & 13.3 & 1.3 & 0.2 & 4.2 & 3.5 & 0.8 & 177.8 & 17.2 & 60.9 & 29.3 & 1.3 \\
\hline 离 & 1495.48 & 1.0 & 0.0 & 0.9 & 10.5 & 2.0 & 0.3 & 3.2 & 2.9 & 0.7 & 137.7 & 28.0 & 35.9 & 15.9 & 64.4 \\
\hline 这 & 1495.90 & 17.8 & 0.4 & 17.4 & 7.7 & 12.7 & 1.1 & 1.9 & 4.1 & 1.7 & 144.0 & 59.6 & 95.6 & 29.1 & 193.1 \\
\hline & 1496.10 & 71.1 & 1.1 & 71.1 & nd & nd & nd & nd & 2.9 & 4.7 & 80.7 & 51.8 & 43.2 & 15.5 & 95.2 \\
\hline & 1496.10 & 75.9 & 1.5 & 75.9 & nd & nd & nd & nd & 2.8 & 5.3 & 75.8 & 51.8 & 42.8 & 15.8 & 100.8 \\
\hline & 1496.52 & 40.9 & 0.6 & 40.9 & nd & nd & nd & nd & 3.2 & 2.9 & 106.4 & 44.4 & 54.1 & 17.9 & 87.9 \\
\hline & 1496.72 & 7.1 & 0.2 & 7.1 & 9.3 & 2.2 & 0.1 & 2.6 & 3.5 & 1.1 & 124.1 & 34.3 & 61.4 & 23.0 & 113.7 \\
\hline & 1569.14 & 1.4 & 0.1 & 1.3 & 8.1 & 3.4 & 0.2 & 1.9 & 3.7 & 0.6 & 113.9 & 32.2 & 44.6 & 17.1 & 95.9 \\
\hline & 1569.76 & 0.8 & 0.1 & 0.7 & 10.9 & 2.5 & 0.1 & 2.9 & 3.5 & 0.8 & 153.9 & 35.9 & 55.5 & 18.2 & 116.4 \\
\hline & 1570.48 & 0.6 & 0.1 & 0.6 & 11.9 & 2.3 & 0.1 & 3.4 & 4.2 & 0.7 & 175.6 & 40.8 & 66.1 & 19.8 & 92.5 \\
\hline$\sim$ & 1571.11 & 0.7 & 0.0 & 0.7 & 11.6 & 2.4 & 0.1 & 3.4 & 3.3 & 0.5 & 175.6 & 42.3 & 63.8 & 19.2 & 94.3 \\
\hline 営 & 1571.44 & 1.1 & 0.0 & 1.0 & 12.6 & 2.6 & 0.1 & 3.8 & 4.0 & 0.6 & 204.1 & 60.9 & 69.0 & 25.2 & 68.2 \\
\hline 学 & 1571.58 & 2.5 & 0.0 & 2.4 & 9.9 & 9.2 & 0.2 & 2.6 & 3.1 & 0.4 & 137.8 & 31.4 & 48.0 & 21.7 & 91.9 \\
\hline & 1571.70 & 93.2 & 0.8 & 93.2 & nd & nd & nd & nd & 1.0 & 2.5 & 189.3 & 31.5 & 69.5 & 23.5 & 37.5 \\
\hline & 1572.04 & 99.4 & 0.7 & 99.4 & nd & nd & nd & nd & 0.2 & 1.8 & 6.6 & 19.7 & 21.4 & 7.8 & 2.5 \\
\hline & 1572.52 & 75.8 & 0.5 & 75.8 & nd & nd & nd & nd & 3.0 & 2.0 & 77.3 & 42.8 & 27.6 & 28.8 & 3.4 \\
\hline & 1573.19 & 0.6 & 0.0 & 0.6 & 10.0 & 2.6 & 0.1 & 2.7 & 3.5 & 0.2 & 127.5 & 30.2 & 58.0 & 21.2 & 93.8 \\
\hline & 881.92 & 0.6 & 0.0 & 0. & 9.1 & 2.8 & 0.2 & 2.5 & 2.8 & 1.2 & 103.3 & 30.0 & 42.6 & 15.3 & 92.3 \\
\hline & 882.87 & 0.5 & 0.0 & 0. & 10.6 & 3.1 & 0.2 & 3.1 & 2.9 & 1.4 & 120.5 & 26.9 & 43.3 & 14.2 & 4.0 \\
\hline & 883.69 & 0.4 & 0.0 & 0.4 & 12.0 & 2.9 & 0.1 & 3.7 & 2.8 & 0.4 & 137.7 & 31.3 & 50.2 & 16.8 & 61.0 \\
\hline & 885.01 & 0.5 & 0.0 & 0.5 & 12.6 & 3.0 & 0.1 & 4.0 & 2.5 & 0.3 & 148.7 & 60.7 & 44.1 & 11.0 & 59.5 \\
\hline & 886.17 & 0.5 & 0.0 & 0.4 & 13.1 & 3.1 & 0.1 & 4.2 & 2.5 & 0.3 & 155.9 & 32.7 & 50.8 & 9.1 & 61.0 \\
\hline$\vec{m}$ & 887.12 & 3.7 & 0.2 & 3.5 & 9.3 & 14.2 & 0.7 & 2.8 & 1.9 & 0.2 & 134.9 & 24.6 & 51.7 & 17.0 & 44.0 \\
\hline 훙 & 887.71 & 1.0 & 0.1 & 1.0 & 12.7 & 4.0 & 0.1 & 4.2 & 2.9 & 0.3 & 171.3 & 41.1 & 62.9 & 23.4 & 92.6 \\
\hline 菂 & 888.34 & 4.9 & 0.1 & 4.8 & 11.8 & 4.8 & 0.2 & 3.9 & 3.4 & 1.2 & 188.1 & 84.3 & 74.6 & 44.8 & 92.9 \\
\hline & 888.62 & 13.9 & 0.3 & 13.9 & 9.7 & 1.7 & 0.0 & 2.4 & 3.3 & 1.1 & 124.5 & 41.8 & 50.2 & 84.0 & 311.7 \\
\hline & 888.86 & 39.3 & 1.1 & 39.3 & nd & nd & nd & nd & 3.2 & 4.6 & 124.2 & 63.6 & 66.6 & 330.7 & 271.9 \\
\hline & 888.91 & 11.7 & 0.4 & 11.7 & 9.8 & 1.9 & 0.0 & 2.5 & 3.1 & 0.9 & 114.8 & 40.2 & 49.1 & 59.0 & 124.9 \\
\hline & 889.21 & 29.5 & 0.5 & 27.0 & 6.3 & 1.7 & 8.3 & 1.5 & 1.6 & 1.2 & 93.0 & 140.6 & 35.5 & 776.0 & 979.3 \\
\hline & 891.12 & 1.4 & 0.0 & 1.3 & 8.7 & 4.3 & 0.2 & 2.3 & 3.1 & 1.1 & 108.8 & 22.8 & 43.7 & 13.5 & 69.5 \\
\hline & 1232.39 & 1.1 & 0.1 & 1.0 & 12.2 & 3.6 & 0.2 & 3.7 & 5.2 & 0.6 & 142.6 & 37.8 & 60.9 & 31.2 & 131.6 \\
\hline & 1232.86 & 2.5 & 0.0 & 2.4 & 11.4 & 8.6 & 0.5 & 3.5 & 5.9 & 0.4 & 188.7 & 46.1 & 51.1 & 48.4 & 104.1 \\
\hline & 1233.80 & 2.1 & 0.0 & 2.0 & 11.6 & 6.9 & 0.3 & 3.6 & 5.9 & 0.5 & 190.7 & 46.6 & 57.9 & 46.3 & 120.7 \\
\hline & 1234.47 & 1.0 & 0.0 & 0.9 & 12.5 & 3.5 & 0.2 & 3.9 & 6.2 & 0.6 & 188.9 & 52.6 & 62.0 & 42.9 & 107.7 \\
\hline N & 1234.99 & 4.3 & 0.2 & 4.2 & 11.7 & 4.4 & 0.2 & 3.5 & 7.3 & 1.9 & 179.5 & 118.1 & 107.0 & 60.0 & 141.0 \\
\hline ơ & 1235.31 & 3.6 & 0.2 & 3.5 & 11.9 & 4.1 & 0.2 & 4.2 & 4.0 & 1.8 & 207.6 & 92.0 & 99.5 & 54.8 & 129.4 \\
\hline 是 & 1235.51 & 7.0 & 0.4 & 7.0 & 11.7 & 2.5 & 0.0 & 3.7 & 5.0 & 1.8 & 183.9 & 137.3 & 111.9 & 60.7 & 1454.7 \\
\hline & 1235.55 & 66.7 & 0.6 & 66.7 & nd & nd & nd & nd & 4.6 & 1.5 & 236.7 & 38.3 & 77.2 & 51.0 & 899.7 \\
\hline & 1235.72 & 79.6 & 0.6 & 79.6 & nd & nd & nd & nd & 1.4 & 2.0 & 55.1 & 34.6 & 36.7 & 30.9 & 79.1 \\
\hline & 1236.15 & 87.2 & 1.0 & 87.2 & nd & nd & nd & nd & 6.9 & 2.4 & 47.9 & 64.6 & 30.3 & 62.6 & 34.6 \\
\hline & 1236.71 & 1.2 & 0.0 & 1.2 & 12.6 & 1.4 & 0.0 & 2.1 & 4.4 & 0.4 & 215.6 & 48.3 & 99.0 & 30.3 & 32.2 \\
\hline
\end{tabular}

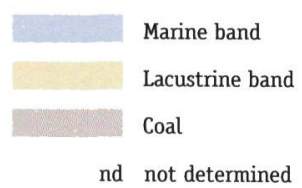

